DEUIFD LII/ 2020, ss. 7-38.

\title{
HİNT ALT KITASI ŞÂFÎิ FIKIH BİRİKİMİNE BİR ÖRNEK OLARAK ZEYNÜDDÎN EL-MELÎBÂRÎ VE FETHU'L-MU‘ÎN Bİ ŞERHİ KURRATI'’L-‘AYN ADLI ESERİ
}

Mehmet Aziz YAŞAR*

\begin{abstract}
ÖZ
Hint Alt Kitası oldukça erken bir dönemde İslâm dini ile tanışmıstır. İslamlaşmaya başlamasıyla birlikte kıtada fikıh mezhepleri de yayılmıştır. Kıtanın kuzey ve orta kesimlerinde Hanefilik hâkim mezhep konumunda olmuştur. Buna mukabil kıtanın güney sahil şeridinde ise Şâfî̀ fikıh anlayışı benimsenmiş ve bu bölgeden çok sayıda Şâfî̂ fakîh çıkmıștır. Bu fakîhlerden biri, şöhreti kıtanın dışına da taşınan Zeynüddîn Ahmed el-Melîbârî'dir. Melîbârî, telif ettiği fikhî çalışmalar ile Şâfîi fikıh literatürünün gelişmesinde ve yayılmasında önemli bir rol oynamıştır. Onun fikı eserleri arasında en çok rağbet gören ise Fethu'lmu în adlı eseri olmuştur. Eser, pek çok ilmî çalışmalara konu edinilmiş ve birçok dile tercüme edilerek geniş bir okuyucu kitlesine kazandırılmıştır. Biz çalışmamızda Melîbârî̀nin Şâfî̀ mezhebinin hâkim olduğu bir bölgenin fakîhi olarak mezhep birikimine katkısını ele aldık. Bu bağlamda Melîbârî̀nin hayatı, ilmî şahsiyeti ve eserleri hakkında bilgiler verdikten sonra Fethu'l-mu'în adlı eseri çerçevesinde onun Şâfî̀ fikıh mirasının gelişimindeki katkısını ortaya koymaya çalış̧tk.
\end{abstract}

Anahtar Kelimeler: Melîbârî, Fethu'l-mu în, Şâfîi, F1kıh, Hint.

\section{ZEYNUDDIN EL-MELIBARI AND HIS WORK IN THE NAME OF FETHU'L-MU'IN BI SHARHI KURRATI'L-'AYN AS A SAMPLE OF INDIC SUBCONTINENT'S SHAFII ISLAMIC LAW KNOWLEDGE}

\section{ABSTRACT}

Indic Subcontinent met with Islam Religion in very early period. The Islamic Law sects were spread across the continent by beginning the islamization. The Hanafism had the central position at the continent's north and middle regions.

* Dr. Öğr. Üyesi, Mardin Artuklu Üniversitesi, İslami İlimler Fakültesi, İslam Hukuku ABD, ya-ar19801@hotmail.com, ORCID ID: https://https://orcid.org/0000-0002-4677-1017.

Makalenin Hakemlere Gönderiliş Tarihi : 06/07/2020

Makalenin Hakemlerden Geliş Tarihi : 10/11/2020 
Furthermore, The Shaffi islamic law perception was adopted in the southern coast line of the continent, and many Shafii scribes appeared in that region. One of those scribes is Zeybuddin Ahmet el-Melibari whose reputation gone out of the continent. Melibari had a great role in the development of Shafii islamic law literature and its transmission with the works including islamic law that he accommodated them. The one in most demand among his islamic law works was the work in the name of Fethu'l-mu'in. The work was discussed in many scientific studies and provided to the large mass of readers as it was translated to many languages. In our research, we considered Melibari's contribution to the sect knowledge as the scribe of a region where The Shafii sect dominated.

Keywords: Melibari, Fethu'l-mu'in, Shafii, Islamic Law, Indic.

\section{GİRIŞ}

Hint kıtasında İslâm dininin yayılması bir anda olmamıştır. Uzun bir süreç sonucunda gerçekleşmiştir. Bu süreç ise $\mathrm{Hz}$. Peygamber zamanında başlamıştır. Rivâyet edildiğine göre Resûlullah (s.a.v.), dönemin Hint kralını İslâm'a davet etmiş; kral da Resûlullah'ı (s.a.v.) ziyaret etmiştir. Bir rivâyet göre ise Resûlullah'a (s.a.v.) hediyeler göndermiştir. ${ }^{1}$ Ancak kaynakların verdiği bilgiye göre Hint'in İslamlaşmasına yönelik ilk somut adım $\mathrm{Hz}$. Ömer döneminde atılıı̧̧ır. Nitekim Hicrî 42 y1lında İslâm devletinin Hint alt kıtasına olan hududunun güvenliği için görevlendirilen İbn 'Âmer Râşid b. 'Amr'in (öl. ?) buraya ilk sefer düzenlediği ve kıtanın derinliklerine kadar indiği ifade edilmiştir. Yine Hicrî 44 y1lında Mulahheb b. Ebî Safre (öl. 82/701) komutanlığında kıtaya büyük bir seferin düzenlediği ve birçok yerleşim yerinin fethedildiği nakledilmiştir. ${ }^{2}$ Emevî ve 'Abbâsî dönemlerinde de

1 Muhammed b. Abdillâh b. Muhammed el-Hâkim en-Nîsâbûrî el-Müstedrek 'ale'ṣSabîhayn,. thk. Mustafa 'Abdulkādir 'Atâ (Beyrut: Dâru'l-Kütübi'l-İlmiyye, 1411/1990), 4/150; Zeynüddîn b. Muhammed el-Melîbârî, Tubfetü'l-mücâhidîn fî ba 'zl abbâri'l-Burtugāiliyyîn, thk. Muhammed Saî̀d et-Tarîhî (Beyrut: Müessesetü'lVefâ, 1405/1985), 77, 223-225; 'Abdulmun'im en-Nemir, Târîhu'l-İslàm fi'l-Hind (Beyrut: el-Müessesetü'l-Câmi‘e li’d-Dirâsât, 1401/1981), 87-88.

2 Muhammed b. Ahmed b. Osmân el-Fârikī ez-Zehebî, Târîhu'l-İslâm ve vefeyâtü'lmeşâhîr ve'l-a 'lâm, thk. Beşşâr 'Avvâd Ma'rûf (b.y.: Dâru'l-Garbi'l-İslâmî, 1424/2003) 2/387-388. 
Hint kıtasına fetih hareketleri sürdürülmüştür. ${ }^{3} \mathrm{Bu}$ seferlerin hemen hepsinin kıtanın batı ve güney şeridine yapıldığ1 ve kuvvetli bir mukavemetle karşılaşmadan sonuçlandığı anlaşılmaktadır. Fetih hareketlerinin yanı sıra kıtanın bu bölgesinin Müslümanlaşmasında Müslüman tüccarlarının ihtida hareketinin de büyük katkısı olmuştur. Zira bahse konu ettiğimiz Melîbârî̀nin de ifade ettiği üzere Araplar ile Melîbâr ${ }^{4}$ halkı arasında ticari ilişkiler nedeniyle çok eskilere dayanan güçlü bir dostluk söz konusu olmuştur. Onlar, bu ilişkilerini İslâm'dan sonra da sürdürmüşlerdir. Bu ilişkiler neticesinde de İslâm Melîbâr bölgesine çok hızlı bir biçimde yayılmıştır. ${ }^{5}$ İslâm'ın Hint kıtasının kuzeyinde bulunan bölgelere yayıllş̧ ise Gazneli Mahmud b. Sebük Tegin (öl. 421/1030) öncülüğünde gerçekleşmiştir. Nitekim Sultan Mahmud'un 392/1002 yılında Kuzey Hindistan'a düzenlediği büyük bir sefer neticesinde Hindu ordusunun yenildiği ve Hint kralının esir alındığı nakledilmiştir. Ayrıca Sultan Mahmud'un bununla kalmayıp, kıtaya 16 sefer daha düzenleyerek İslâm'ın Hint kıtasında güçlenmesinde büyük katkı sunduğu belirtilmiştir. İşte Müslümanların bu çabaları sayesinde İslâm, Hint alt kıtasında ikinci büyük din olarak yerini almıştır. ${ }^{6}$ 2011'de yapılan nüfus sayımına göre Hint kıtasında Müslüman nüfusu 172 milyon olarak tespit edilmiştir. Bu da ülkenin toplam nüfusunun \%14,2'ye tekabül etmektedir.

İslâm'1 benimsemesiyle birlikte Hint halkına İslâm dininin hükümlerini öğretmek için birçok âlim Hindistan'a gelip yerleşmişlerdir. Söz konusu âlimler, bir yandan yeni Müslüman olanlara İslamiyet'i anlatmış, diğer yandan ilmî kurumlar inşa ederek ilim öğretmişlerdir. Keza kıtadan da pek çok kişi, ilim tahsili için Hicaz başta olmak üzere

3 Ebu'l-Fidâ İsmâil b. Ömer İbn Kesîr, el-Bidâye ve'n-nihâye (b.y.: Dâru'l-Fikr, 1407/1986), 9/104,113; 11/324, 379.

4 Malabar adıyla anılan bu bölge, Kuzeyde D'eli dağından güneyde Komorin Burnu'na kadar uzanan yaklaşık 550 kilometrelik bir kıyı şeridi kapsamaktadır. Azmi Özcan, Türkiye Diyanet Vakefi İslâm Ansiklopedisi, (Ankara: TDV Yayınlar1, 2003), 27/465-466.

5 Melîbârî, Tuhfetü'l-mücâhidîn, 77, 223; Nemir, Târîhu'l-İslâm fi'l-Hind, 87-88.

6 Nemir, Târîhu'l-İslâm fi'l-Hind, 111-133; Muhammed Tayyib Kılıç, "Hint Alt Kıtası Hanefî Fikıh Birikimine Bir Örnek: Fakih Olarak İmâm Leknevı̂”. 16/1 (2014), 89140.

7 https://tr.wikipedia.org/wiki/Hindistan\%27da_\%C4\%B0slam, erişim tarihi: 28.5.2020. 
İslâm beldelerine gitmişlerdir. ${ }^{8}$ Kitaya gelen âlimler, doğal olarak bağlı bulundukları mezhep doktrinini öğretmiş ve bunu yaymaya çalışmışlardır. Aynı şekilde ilim öğrenmek için kıta dışına çıkanlar da tahsil gördükleri hocalarının etkisinde kalarak onların mezheplerini benimsemiş ve memleketine döndüklerinde bu mezheplerin öğretilerini yaymışlardır. Netice itibariyle de Hint kıtasında Sünni mezheplerden Hanefilik ve Şâfiîlik ağırlıkta olmuştur. Kıtada bu mezheplerin yayılışında ise kıtanın bu mezheplerin hâkim olduğu bölgelere yakın olması etkili olmuştur. Nitekim Hanefiliğin hâkim konumda olduğu Mâverâünnehir ve Horasan bölgelerine yakın olan kıtanın kuzey ve orta kesimlerinde sözü edilen mezhep yoğunlukta olmuştur. Zira İslâm'ın yayılışıyla birlikte Hanefî âlimleri kıtanın kuzeyine akın etmiş; burayı fetheden Hanefî Türk sultanlarının desteğiyle birçok ilmî kurum inşa ederek yoğun bir ilmî faaliyet yürütmüşlerdir. Keza bölgenin Müslüman yerlileri de kendilerine yakın olan sözü geçen İslâm beldelerine ilim tahsili için gitmiş; bunlardan bazıları ilim icazetini aldıktan sonra memleketine dönmüş ve buralarda Hanefî mezhebinin öğretisini yaymışlardır. Bunun sonucunda da Hint kökenli meşhur pek çok Hanefî fakîh yetişmiş ve kıtada muazzam bir Hanefî fikıh birikimi oluşmuştur. ${ }^{9}$ Buna karşılık Hint kıtasının güney kesiminde ise -Şâfiî mezhebinin ağırlıkta olduğu Hicaz, Şîrâz ve Yemen bölgelerine yakın olduğu için- Şâfîllik tercih edilmiştir. Fıkhî mezheplerin teşekkülünden itibaren Şâfî̀ fakîhler bu bölgelere gitmiş; medreseler inşa ederek bu bölgeleri ilim merkezleri haline dönüştürmüştür. Aynı zamanda kıtanın yerlileri de sözü edilen İslam beldelerine ilmî yolculuklar yaparak buralarda bulunan Şâfîi fakîhlerden fikıh ilmini öğrenmiş ve bilahare kıtaya dönerek burada Şâfî̀ fikıh anlayışının yerleşmesini sağlamışlardır. Bu tür ilmî faaliyetlerin semeresi olarak da kıtanın güney kesiminde Hint asıllı birçok Şâfî̀ fakîh yetişmiştir. Bunlar, Şâfî̀ mezhebinin temel prensiplerini esas alarak büyük bir fikıh mirasını ortaya

8 Abdülhayy b. Fahriddîn b. Abdilalî el-Hasenî, Nüzhetü'l-havâtur ve behcetü'l-mesâmi ' ve'n-nevâzır (Beyrut: Dâru İbn Hazm (1420/1999), 1/67, 82, 105, 128; 'Abdunnesîr Ahmed el-Melîbârî, Terâcimu 'ulemâi'ş-Şâfiîyye fi'd-diyâri'l-Hindiyye, (b.y.: Dâru'l-Kalem li'd-Dirâsat ve'n-Neşri, tsz.), 12.

9 'Abdulhay el-Hüsnî, es-Sikâfetü'l-İslâmiyye fi'l-Hind (Kahire: Müessesetu Hindâvî li'tTa'lîm ve’s-Sikâfe, 2015), 99-111 
koymuşlardır. ${ }^{10}$ Sözünü ettiğimiz fikhî mirasının oluşumunda önemli bir yer işgal eden fakîhlerden birisi Zeynüddîn el-Melîbârî'dir. Melîbârî, Şâfî̀ fikhına dair kendi muhtasar eseri üzerinde yazdı̆̆1 Fethu'l-mu în bi-şerbi Kurreti'l-'ayn adlı şerh çalışmasıyla Şâfiî muhitinde büyük bir üne kavuşmuştur. Çalışmamızdan amaç Melîbârî’nin bu eseri çerçevesinde Şâfî̀ mezhebindeki önemine dikkat çekmektir.

\section{Melîbârî’nin Hayatı İlmî Şahsiyeti ve Eserleri}

\section{A. Nesebi ve Doğumu}

Kaynaklarda hayatı hakkında yeterli bilgi bulunmayan Melîbârî, bünyesinden birçok meşhur âlimin çıtığı Mahdûmiyye ailesine mensuptur. Köklü bir ilmi geleneğe sahip Mahdûmiyye ailesi, Hint alt kıtasının güneyinde bulunan Kilâkarâ (Keelakarai) vilayetinin soylu ailelerindedir. Mahdûmiyye ailesi İslâm'ın bölgede yayılmasında büyük katkı sağlamıştır. Ayrıca ailenin içinden çıkan âlimler, bölgede büyük medreselerin inşasına öncülük etmiş ve Hindistan'ın güneyinde ilmin yayılmasında büyük rol oynamışlardır. Fennân'da kurulan el-Câmi'u'lKebîr bu medreselerin başında gelmektedir. Mahdûm ailesine mensup âlimler, söz konusu medresede uygulanan tedrisat metodunu esas alarak bölgenin birçok yerleşim yerinde bulunan mescitlerde ders halkaları oluşturmuşlardır. Öyle ki Hindistan'da Mahdûm ailesine nispetle "Mahdûmiye metodu" olarak bir ilmi gelenek oluşmuştur. Aileye mensup âlimlerin bu çabaları sonucunda başta Melîbâr bölgesi olmak üzere ülkenin güneyinde bulunan vilayetlerin her biri, birer ilim merkezi haline dönüşmüştür. ${ }^{11}$ Amelî mezhep olarak Şâfîlliği benimseyen Mahdûmiyye ailesi Hint alt kıtasında Şâfiî mezhebinin bayraktarlı̆̆ını yapmıştır. ${ }^{12}$ Sözü edilen ailenin önemli bir siması Zeynüddîn el-Melîbârî’dir. Melîbârî̀nin isim ve nisbesi ise şu şekildedir: Ahmed Zeynüddîn b. Muhammed elGazzâlî $^{13}$ b. Zeynüddîn Ebî Yahya b. Alî b. Ahmed el-Mahdûmü's-Sağî̀ ${ }^{14}$

10 Melîbârî, Terâcimu 'ulemâi'ş-Şafiùyye, 11-13.

11 Rafîk Abdulberr el-Vâfî el-Ezherî, "eş-Şeyh Ahmed Zeynüddîn el-Mahdûm elMelîbârî ve hademâtuhu", Sikâfetü'l-Hinde Mecelletün İlmiyyetün Sikâfíyyetün, 64/3 (2013), 132.

12 Ezherî, "eş-Şeyh Ahmed Zeynüddîn el-Mahdûm el-Melîbârî ve hademâtuhu", 121 122.

13 Bazı kaynaklarda müellifimizin babasının ismi Abdulazîz olarak geçmektedir. Fakat müellif el-Ecvibetü'l-'acîbe ani'l-es'ileti'l-garîbe adlı eserinin mukaddimesinde babasinın 
el-Ma‘berî el-Melîbârî (Malabar) el-Fennânî’dir. Daha çok yaşadığ1 bölgenin ismine nisbetle el-Melîbârî olarak anılmıştır. Melîbârî̀nin doğum yeri ile ilgili farklı rivâyetler bulunmaktadır. Kendisinden söz eden kaynakların bir kısmı Melîbârî’nin Fennâ (Ponnani) vilayetinde, bir kısmı Kûşen şehrinde, diğer bir kısmı ise Kannur vilayetine bağlı Côbân (Chombal) köyünde doğduğunu kaydetmiştir. Son rivâyet daha isabetli görülmüştür. ${ }^{15}$ Yine Melîbârînin doğum tarihine ilişkin rivâyetler farklılık göstermekle beraber 938/1532 y1lında doğmuş olmasına dair rivâyet daha kuvvetli kabul edilmiştir. ${ }^{16}$

\section{B. Tahsili ve Yetişmesi}

Yedi yaşında Kur'an-i kerimi hıfzeden Melîbârî, ilk ilim tahsilini memleketinde ilim ve edep sahibi olan Mahdûmiyye ailesinin önemli bir üyesi olan babası Muhammed el-Gazzâlî'den almıştır. Küçük yaşta babasını kaybeden Melîbârî, amcası Abdulazîz el-Melîbârî̀nin himayesine girmiş ve tahsilini onun yanında sürdürmüştür. Memleketinde ilk tahsilini tamamladıktan sonra Melîbârî, ilim merkezi olan Mekke'ye gitmiştir. Mekke'de on yıl kalan Melîbârî burada bulunan meşhur birçok âlimden farklı ilim dallarında ders almıştır. Melîbârî’nin ilim tahsilini gördüğü bu âlimlerden bazıları şunlardır:

1) Ebü'l-Hasen Tâcülârifîn Muhammed b. Muhammed b. Abdirrahmân es-Siddîkī (öl. 952/1545). 889/1493'te Kahire'de doğmuş ve burada yetişmiştir. Zekeriyyâ el-Ensârî̀nin (öl. 926/1520) öğrencisidir. Anlatıldığına göre sedyeyle hacca giden ilk kişi olarak tarihte yerini

ismi Muhammed el-Gazzâlî olarak vermiştir. Abdulazîz ise onun amcasıdır. Zeynüddîn Ahmed b. Muhammed el-Melîbârî, el-Ecvibetü'l-'acibe ani'l-es'ileti'l-garîbe (Hindistan: Dâru't-Tabâ'ati ve'n-Neşr, (tsz.), 2; Ahmet Özel, "Melîbârî”, Türkiye Diyanet Vakfi İlâm Ansiklopedisi (Ankara: TDV Yayınları, 2004), 29/48-49.

14 Kalkaşendî "mahdûm” un önemli işlerin yazışmasıyla ilgilenenler için kullanılan bir unvandır demektedir. Ebü'l-'Abbâs Ahmed b. Alî el-Kalkaşendî, Subhu'l-a 'şâ fî̀ sınâ'ati'l-inşâ (Beyrut: Dâru'l-Kütübi'l-İlmiyye, tsz.), 6/27. Burada ise Mahdûm ifadesi hicrî dokuzuncu asırdan itibaren Fennân vilayetinde bulunan el-Câmi'u'lKebîr külliyesinde kâdılık görevini yapan âlimler için kullanılan bir unvandır.

15 İsmâil Paşa Bağdatlı, Hediyyetül-ârifin, (İstanbul: Matba'atü’l-Behiyye, 1370/1951), $1 / 377$.

16 Melîbârî, Terâcimu 'ulemâi'ş-Sâfî̀yye, 81. 
almıştır. Sıddîkī, vefatına değin sırayla bir yıl Kahire'de, bir yıl Mekke'de ikamet etmiştir. İlim dünyasında birçok eser armağan ederek 952/1545'te Kahire'de vefat etmiştir. ${ }^{17}$

2) Ebü’l-Abbâs Şihâbüddîn Ahmed b. Muhammed b. Muhammed el-Heytemî es-Sa'dî (öl. 974/1567). 909/1503'te Misır'in Garbiye bölgesindeki Heyâtim köyünde dünyaya gelmiştir. Tahsilinin önemli bir bölümünü Ahmediyye Medresesi'nde ve Ezher'de tamamlamıştır. Şâfiî fikhında uzmanlaşan Heytemî, mezhebin fikıh birikimini gözden geçirerek adeta yeniden ortaya koymuş ve müteahhir Şâfiî fakîhler üzerinde büyük bir etki bırakmıştır. Muteahhirîn Şâfiî fakîhleri arasında mutemet kabul edilen iki fikhî eğilimden birinin sahibi olan Heytemî, 974/1567 tarihinde Mekke'de vefat etmiştir. ${ }^{18}$

3) Ebu'd-Diyâ Vecîhuddîn b. Abdirrahman b. Abdilkerîm b. Ziyâd el-Yemenî ez-Zebîdî (öl. 975/1568). 900/1495'te Yemen'in tarihî şehirlerinden olan Zebîd'de doğmuştur. Memleketi Zebîd'de tahsilini tamamladığ1 belirtilen Ebu'd-Diyâ Şâfî̀ mezhebinin tertipleyicisi olarak anılmaktadır. Müftîlenâm olarak ün yapan Ebu'd-Diyâ'nın birçok fetvâ çalışması bulunmaktadır. Ebu'd-Diyâ, 975/1568'de memleketinde vefat etmiştir. ${ }^{19}$

4) İzzüddîn b. Abdilazîz b. Alî b. Abdilazîz eş-Şîrâzî el-Mekkî ezZemzemî (öl. 976/1569). 900/1495’te Mekke'de doğmuş ve burada ilim tahsilini yapmış Şâfiî bir fakîhtir. Aynı zamanda bir şair olarak da tanınan Zemzemî, 952/1545'te Hicaz'dan Şam'a oradan da Anadolu'ya geçmiştir. 976/1569 yilında İstanbul'da vefat etmiştir. ${ }^{20}$

17 Muhammed Hayrüddîn b. Mahmûd ez-Ziriklî, el-A 'âm, Bask1 15 (b.y.: Dâru'l'İlim li'l-Melâyin, 1423/2002), 7/57.

18 Hacı Halife Mustafa b. Abdullah Kâtib Çelebî, Süllemü' '-vüsûl ilâ tabakäti'l-fubûl, thk. Mahmud Abdulkādir Arnaût (İstanbul: Mektebetu İrsîkâ, 1431/2010), 1/230; Cengiz Kallek, "İbn Hacer el-Heytemı̂", Türkiye Diyanet Vakfi İslam Ansiklopedisi (Ankara: TDV Yayınları, 1999), 19/531-532.

19 Muhyüddîn 'Abdulkādir b. Abdillah el-'Ayderûs, en-Nûrn's-sâfir 'an abbâri'l-karni'l'âsir (Beyrut: Dâru'l-Kütübi'l-İlmiyye, 1405/1985), 273-274; Yusûf Muhammed 'Abduh Muhammed el-'Avvâdî, "el-'Allâme Abdurrahman b. Ziyâd el-Maksarî ve cühûdu'l-ilmiyye ve eseruhu 'alâ talebeti'l-'ilmi ve'l-muctame", Mecelletu Câmi'ati'lMedinetill-Âlemiyye, 17 (2016), 145-146.

20 'Ayderûs, en-Nûru's-sâfir', 287. 
5) Şeyhulislâm Abdilazîz b. Zeynüddîn el-Mahdûmü'l-Kebîr elMelîbârî (öl. 994/1586). 911/1505 tarihinde doğmuştur. Bahsimize konu olan Ahmed Melîbârî'nin amcasıdır. Fennân'da bulunan el-Câmi'u'lKebîr'de müderrislik ve kâdılık vazifelerini yapmıştır. Abdilazîz, 994/1586'da Fennân'da vefat etmiştir. ${ }^{21}$

Bunun yanın sıra Melîbârî, Şemsüddîn Muhammed b. Ahmed b. Ahmed b. Hamza er-Remlî (öl. 1004/1596), Şemsüddîn Muhammed b. Ahmed el-Hatîb eş-Şirbînî el-Kāhirî (öl. 977/1570) ve Takiyuddîn Abdullah b. Abdullah b. Ahmed Bâhurme eş-Şeybânî (öl. 972/1565) gibi dönemin önemli Şâfî̀ fakîhleri ile görüşmüş ve önemli fikhî meseleler hakkında onlarla bilgi teatisinde bulunmuştur. ${ }^{22}$

\section{C. İlmî Şahsiyeti}

Melîbârî, on yll gibi uzun bir süre ilim merkezi Mekke'de yoğun bir tahsil faaliyetinde bulunmuştur. Bu sürede her biri kendi alanında otorite saylan pek çok âlimden ders alarak genel olarak bütün dinî ilimlerde özellikle de fikıh ilminde derin bir vukûfiyete sahip olmuştur. Farklı ilim dallarında icazet aldıktan sonra memleketine dönen Melîbârî, amcası Abdulazîz'in de müderrisliğini yaptığı Fennân'daki el-Câmi'u'lKebîr'de müderris olarak göreve başlamıştır. Kısa sürede şöhreti her tarafa yayllan Melîbârî büyük bir teveccüh görmüş ve İslâm âleminin her tarafından talebeler ilim tahsili için kendisine yönelmiştir. Yaklaşı otuz altı yıl gibi uzun bir süre el-Câmi'u'l-Kebîr'de tedrisat yapan Melîbârî çok sayıda talebe yetiştirmiştir. Melîbârî̀nin öne çıkan bazı talebeleri şunlardır:

1) Kâdî Cemâlüddîn Muhammed b. eş-Şeyh el-Kâdî Nâsiruddîn Abdulazîz el-Kâlîkûtî el-Melîbârî (öl. 1025/1616). 980/1572 tarihinde Kâlîkût'ta doğmuştur. Kâlîkût'ün meşhur kâdılarındandır. Asıl uzmanlık alanı Arap dili ve edebiyatı olmakla beraber fikı ilminde de kendisini geliştirmiştir. ${ }^{23}$

21 Melîbârî, Terâcimu 'ulemâi'ş-Şâfîyye, 80.

22 Hasenî, Nü̈hetü'l-havâtır, 4/341; Melîbârî, Terâcimu 'ulemâi's-Şâfî̀yye, 81-83; Özel, "Melîbârî", 29/48.

23 Hasenî, Nü̈hetül-havâtır, 4/411. 
2) Abdurrahman b. Osman el-Ma‘berî el-Fennânî el-Melîbârî (öl. 1029/1619). Mahdûmiyye ailesinin önemli bir üyesi olan Abdurrahman el-Melîbârî̀nin 948/1541'de Fennân'da doğduğu tahmin edilmektedir. İlim tahsilini babası Osman, dayısı Abdulazîz ve kuzeni Zeynüddîn elMelîbârî̀'den almıştır. ${ }^{24}$

3) eş-Şeyh el-'Allâme el-Kâdî Cemâlüddîn b. Şeyh Osman elMa‘berî el-Fennânî (öl. ?). Abdurrahman b. Osman el-Ma‘berî̀nin kardeşedir. Hayatı hakkında bilgiye rastlanmadık. ${ }^{25}$

4) eş-Şeyh el-İmâm Osman Lebbâ el-Kâhırî (öl. ?). Aslen Hindistan'ın Tâmil Nâd vilayetine bağlı Kâhir Feten'dendir. Bunun dışında kaynaklarda Osman Lebbâ hakkında bir bilgiye rastlamadık. ${ }^{26}$

5) eş-Şeyh el-Kâdî Süleyman el-Kâhırî (öl. ?). Onun da Osman Lebbâ gibi aslen Hindistan'ın Tâmil Nâd vilayetine bağlı Kâhir Feten'den olduğu belirtilmektedir. ${ }^{27}$

Melîbârî̀nin ilim tedrisatının yanı sıra tasavvufla da ilgilendiği bilinmektedir. Zira Melîbârî, ilim tahsili için Mekke'de bulunduğu sırada Kâdıriyye tarikatının temsilcilerinden Ebu'l-Hasen el-Bekrî es-Sıddîkîye intisap etmiş ve ondan tasavvufun adap ve arkânını öğrenerek icazetini almıştır. Melîbârî'nin amcası ve hocası Zeynüdddîn Abdulazîz'in tasavvuf erbabından olup bu konuda eser telif ettiği de bilinmektedir. Melîbârînnin aynı zamanda hocası olan amcası Abdulazîz'den etkilenmemesi ise düşünülemez. Ayrıca Melîbârî’nin diğer hocalarından bazılarının tasavvuf erbabından olması da onu bu yönde etkilemiş olmaları kaçınılmazdır. ${ }^{28}$ Nitekim onun en çok etkilendiği hocalarından İbn Hacer el-Heytemî tasavvuf müntesiplerindedir. ${ }^{29}$ Zaten Melîbârî’nin fikıh eserlerinin tasavvuf erbabinca benimsenmesi ve tasavvuf ehli medreselerde yaygin bir şekilde kullanılması bunu göstermektedir. Osman b. Muhammed Şetâ

24 Ezherî, "eş-Şeyh Ahmed Zeynüddîn el-Mahdûm el-Melîbârî ve hademâtuhu”, 131.

25 Melîbârî, Terâcimu 'ulemâi'ş-Şafî̀yye, 85.

26 Melîbârî, Terâcimu 'ulemâi's-Şâfî̀yye, 85.

27 Melîbârî, Terâcimu 'ulemâi’ș-Şafiûyye, 85; Ezherî, "eş-Şeyh Ahmed Zeynüddîn elMahdûm el-Melîbârî ve hademâtuhu", 132.

28 Melîbârî, Terâcimu 'ulemâi's-Şâfiuyye, 85

29 Ebû Sehl Muhammed b. Abdirrahman el-Meğrâvî, Mevsû́atu mevâkifi's-selef fi'l- 'akîde ve'l-menhec ve't-terbiyye (Misir: el-Mektebetü'l-İslâmiyye, tsz.), 8/536. 
ed-Dimyâtî'nin (öl. 1310/1893), Melîbârînnin Fetbu'l-mu'în adlı eserine yazdığı haşiyesinin sonunda sarf ettiği şu sözler önem arz etmektedir: “Fetbu'l-mu'în' in faydası doğudan batiya ve kuzeyden güneye kadar bütün İslâm âlemini kapladı. Çünkü bu eserin müellifi tasavvufun büyüklerindedir."

Sultan Ekber Şâh el-Moğolî (öl. 1014/1605), I. Alî Âdilşah (öl. 988/1579) ve Sultan Mahmud Alî Âdil Şâh (öl. 1037/1628) dönemlerinde yaşadığı bilinen Melîbârî̀nin siyasî ve sosyal faaliyetlerde de bulunduğu bilinmektedir. Melîbârî̀nin sözü geçen her üç lider ile iyi ilişskileri olmuştur. Aynı şekilde onun diğer devlet adamları ve bürokratları ile dostane ilişkiler kurduğu gibi komşu memleketlerin yöneticileriyle de iyi ilişkiler geliştirdiği kaydedilmiştir. ${ }^{31}$ Diğer taraftan Melîbârî̀nin münzevi bir hayat yaşamadığ 1 , aksine içinde yaşadığ toplumun sorunlarıyla ilgilendiği ve toplumun üzüntü ve sevinçlerine ortak olduğu görünmektedir. Zaten Melîbârî̀nin kaleme aldığ1 fetvâ risâlelerinin daha ziyade kendisine yöneltilen sorulara cevap şeklinde olması onun içinde yaşadığı toplumun sorunlarından ve gündeminden kopuk olmadığını göstermektedir. Melîbârî, sömürgeci güç olarak bölgede bulunan Portekizler'in bölge halkına yaptığı zulüm ve hakaretlere karşı kayıtsız kalmayarak onlara karşı cesur ve onurlu bir duruş sergilemiştir. Ayrıca toplumun bir dinî lideri olarak Melîbârî̀, Portekizler’in yaptı̆̆ı zulme karş1 halk1 bilinçlendirmiş ve bütün bölge halkının birlikte onlara karşı mücadele etmesini sağlamıştır. Bu konuda kaleme aldığı Tübfetü'lmucâbidîn fì ba'di abbâri'l-burtăgăliyyîn büyük önem taşımaktadır. Melîbârî bu eserini dönemin sultanı Alî 'Âdil Şâh'a ithaf ederek onun Melîbâr halkının Portekizlere karşı verdiği mücadeleye destek olmasını istemiştir. $^{32}$

30 Osman b. Muhammed Şetâ el-Bekrî ed-Dimyâtî, I'ânetü't-tâlibîn 'alâ halli elfâzi Fethu'l-mu'în (b.y.: Dâru'l-Fikr li't-Taba'ati ve'n-Neșr ve't-Tavzî', 1418/1997), 4/389.

31 Melîbârî, Terâcimu 'ulemâi'ş-Şâfîyye, 85.

32 Melîbârî, Tubfetül-mücâbidîn,25-26, 196-198. 


\section{Eserleri}

Melîbârî bir yandan tedrisat, irşâd ve cihâd faaliyetlerinde bulunmuş diğer yandan farklı ilim dallarında birbirinden kıymetli birçok eser telif etmiştir. Melîbârî köken itibariyle Arap olmamasina rağmen bütün eserlerini fasih bir Arapça ile yazmıştır. Bu eserlerinin yazımında ise tıpkı fasih bir Arap gibi sade ve akıcı bir dil kullanmıştır. Öyle ki onun aslen Arap olduğunu söyleyen tarihçiler bile olmuştur. ${ }^{33} \mathrm{Bu}$ da onun Arap dili ve edebiyatındaki maharetini göstermek açısından kayda değerdir. Melîbârî farklı alanlarda eser vermiş olsa da fikıh alanında daha fazla öne çıkmış ve eserlerinin büyük kısmı bu alan ile ilgili olmuştur. Burada Melîbârî’nin eserlerini iki başlikta ele alacağız. Konu bütünlügünün sağlanması bakımından önce onun fikıh dışındaki çalışmalarını, ardından da esas konumuz olan fikıh ile ilgili eserlerini açıklayacağız.

\section{Melîbârî’nin Fıkıh İlmi Dışındaki Eserleri}

a. el-Cevâhir fì 'ukûbeti ebli'l-kebâir. Eser zina yapmak, içki içmek, faiz yemek, haksız yere adam öldürmek, namazı terk etmek ve zekâtı vermemek gibi günahların cezasına ilişkin bilgileri içermektedir. Ayrıca Melîbârî eserde musibete karşı sabır ve tahammül gösterenlerin nail olacakları mükâfatından ve erkeğin kadın üzerindeki haklarından da bahsetmiştir. ${ }^{34}$

b. el-Isti'dâdu li'l-mevt ve su'âlï'l-kabr. Vaaza dair bir eserdir. Melîbârî, eserde Müslümanların kalplerini iyiliğe ısındıracak ve kötülüklerden uzak tutacak bir takım dinî ve ahlâkî konuları nasihat tarzında sunmuştur. Melîbârî̀nin eserin önsözünde belirtiği gibi eserde zikredilen konulara dair âyet ve hadislerin yanı sıra konuya ilişskin salihlerden nakledilen bazı hikâyeleri, âlimlerin tavsiyeleri ve hikmetli şiirler de irad edilmiştir. ${ }^{35}$ Eserin son kısmında ise kıyamet gününün dehşetinden bahsetmiştir. ${ }^{36}$

33 Ezherî, "eş-Şeyh Ahmed Zeynüddîn el-Mahdûm el-Melîbârî ve hademâtuhu”, 123.

34 Zeynüddîn b. Abdilazîz b. Zeyniddîn b. Alî el-Melîbârî, el-Cevâhir fî̀ 'ukûbeti ebli'lkebâir (Beyrut: Dâru'l-Kütübi'l-İlmiyye, 1402/1982), 6-33 vd.

35 Zeynüddîn b. Abdilazîz b. Zeyniddîn b. Alî el-Melîbârî, el-İsti 'dâdu li'l-mevt ve su'a alü'kabr, thk. Sa'îd Kerîm ed-Dir'amî (İskenderiye: Dâru İbn Haldûn, tsz.), 5.

36 Melîbârî, Terâcimu 'ulemâi'ş-Şâfîyye, 87. 
c. Mubtasaru Serbi's-sudûr fî abvâli'l-mevtâ ve'l-kubûr. Celâlüddîn esSüyûtî’nin (öl. 911/1505) ölüm ve kabir ile ilgili varid olmuş rivâyetlerin derilmesinden ibaret olan Şerbi's-sudûr fì abvâli'l-mevtâ ve'l-kubûr adlı eserinin muhtasaridır. ${ }^{37}$

d. Tubfetü'l-mücâbidîn fì ba 'ì abbâri'l-Burtugäliyyinn: Tarih ve siyaset alanlarında yazılan ve müellifine ün kazandıran önemli bir eserdir. Hint alt kıtasının İslamlaşmasına dair önemli bilgiler içermektedir. ${ }^{38}$ Eser dört bölümden oluşmaktadır. Birinci bölümde cihadla ilgili hükümlere yer verilirken cihâdın faziletinden bahsedilerek Müslümanalar cihâda teșvik edilmiştir. İkinci bölümde Melîbâr bölgesinde İslâm dininin yayllışından bahsedilmiştir. Üçüncü bölümde Melîbâr'da yaşayan gayr-i müslimlerin bir takım geleneklerinden söz edilmiştir. Dördüncü bölümde Portekizliler'in Melîbâr'da kaldıkları döneme (1498-1583) dair bilgiler verilmiştir. $^{39}$

\section{Melîbârî’nin F1kıh İlmiyle İlgili Eserleri}

Melîbârî̀nin fikıh alanında telif ettiği bütün eserleri fürû'-i fikıhla ilgilidir. $O$ usûl ile ilgili her hangi bir eser telif etmemiştir. Ayrıca Melîbârî̀nin İrşâdü'l- 'ibâd ilâ sebîli'r-reşâd adlı eseri, fikhî konuların yanı sıra akaid, tasavvuf, kıssa ve vaaza ilişkin konuları da içerdiği için bazı tarihçiler ve araştırmacılar tarafından vaaz türü eserlerden addedilmiştir. Ancak eserin muhtevası ağırlıklı olarak fikıh konularından müteşekkil olduğu için biz onu fikıhla ilgili eserler kısmında zikrettik.

a. Kurretü'l-'ayn fî mübimmâti'd-dîn: Küçük bir takım takdim ve tahirler dışında hem sistematik hem de içerik bakımından geleneksel muhtasar Şâfî̀ fikıh tarzında gayet veciz ifadelerle yazılmış bir metindir. Eser, gerek Melîbâr'da gerekse Şâfiîliğin hâkim olduğu diğer muhitlerde büyük bir teveccüh görmüştür. Eser gereğinden fazla ihtisar edildiği için ilim talebeleri onun ifadelerini anlamakta zorluk çekmiştir. Bunu fark eden müellif, onu Fethu'l-mu'în bi şerbi Kurrati'l-'ayn adıyla şerh etmiştir. Esasında Şâfî̀ fikıh literatürüne baktığımızda muhtasar fikıh metinlerinin,

\footnotetext{
37 Melîbârî, Terâcimu 'ulemâi'ş-Şâfîyye, 87.

38 Melîbârî, Tubfetü'l-mücâhidîn, 223-233.

39 Ziriklî, el-A 'lâm, 5/238; Özel, "Melîbârî", 29/48.
} 
müellifleri tarafından şerh edilmesi veya üzerinde haşiye çalışmasının yapılması olayı Melîbârî ile başlamadığını; daha önceye dayanan bir gelenek olduğunu görüyoruz. Nitekim mezhebin tenkîh döneminin "Şeyhâyn"'inden biri olan Nevevî (öl. 676/1277) de Minhâau't-tâlibîn adlı eserine Dekâiku'l-minhâc adında bir çalışma yaparak bunu gerçekleştirmiştir. Kurrati'l-'ayn metni Malîbâr medreselerinde yaygin bir şekilde ders kitabı olarak kullanılmıştır. Keza Malîbâr dışındaki medreselerde de uzun bir zaman okutulduğu belirtilmiştir. ${ }^{40}$ Ayrıca eser üzerinde şu çalışmalar da bulunmaktadır: Muhammed b. Ömer Nevevî el-Câvî'nin (öl. 1316/1898): Nihâyetü'z-zeyn fî irşâdil-mübtedi'în șerbün 'alâ Kurreti'l-'ayn bi mubimmâti'd-dîn'1, Muhammed b. Muhammed el-'Ukaylî eşŞâfîìnin (öl. 1365/1946) el-Mu'în li naz̧mi Kurrati'l-'ayn's, Muhammed Musliyâr el-Melîbârînnin (öl. 1371/1952) Nazmu kurrati'l-'ayn li metni Fethi'l-mu'în'1, Ebû Süheyl Enver Abdullah b. Abdirrahman elMelîbârî'nin en-Nažmu'l-vefî fi'l-fikbi'ş-Şâfî si. ${ }^{41}$

b. İşâdü'l-ibâd ilâ sebîli'r-reşâd: Malîbârî, bu eserini hocasi İbn Hacer el-Heytemî'nin ez-Zevâair 'an iktirâfi'l-kebâir ve dedesi Zeynüddîn b. Alî el-Melîbârî̀nin Murşidü't-tullâb adlı eserlerini esas alarak hazırladığını belirtmiştir. ${ }^{42}$ Eser fikıh, akâid, tasavvuf ve vaaz gibi pek çok konuyu kapsayan zengin bir içeriğe sahiptir. Melîbârî, eserini her mükellefin bilmesi gereken itikadî bazı konuların açıklamasıyla başlamıştır. ${ }^{43}$ Ardından ilmin faziletini, Müslüman çocukların öncelikli olarak öğrenmesi gereken meseleleri; temizlik, namaz, zekât, hac ve oruç konularını (bunların faziletine dair âyet ve hadislerle birlikte); muâmelât ile ilgili bazı konuları; Müslümanların uzak durması gereken büyük günah ve manevî hastalıkları; ahlakı arındırmaya yönelik ögütleri serdetmiştir. Alî eş-Şerbecî ve Muhyüddîn Necîb eseri Tervîhu'l-fuâd: Mubtasaru kitabi İş̧âdi'l- 'ibâd ilâ sebîli'r-reşâd ismiyle ihtisar etmişlerdir. Eser halen

40 Komisyon, Indian writings in Arabic (Unversity of Calicut School of Distance Education), 27

41 Melîbârî, Terâcimu 'ulemâi'ş-Şâfîyye, 89.

42 Zeynüddîn Ahmed b. Muhammed el-Melîbârî, İrşâdül- 'ibâd ilâ sebîli'r-reşâd (b.y.: Dâru'l-Ma'rife, tsz.), 1.

43 Melîbârî, İşâdüll- 'ibâd, 2-20. 
Melîbâr'da ve Hindistan'in diğer bölgelerinde bulunan bazı İslâmî ilimler enstitüsü ve fakültelerde ders kitabı olarak okutulmaktadır. ${ }^{44}$

c. İhkâmu abkâmi'n-nikâh: Eser, Melîbârî'nin bazı akranının, kendisinden nikâh ile ilgili geniş bir risâlenin telifini israrla istemesi üzerine kaleme alınmıştır. ${ }^{45}$ Melîbârî, risâlenin girişinde evlenmenin teşvikine yönelik bir takım âyet ve hadislere yer vermiştir. Sonrasında nikâh ve talak konularını kapsamlı bir şekilde ele almıştır. ${ }^{46}$ Melîbârî, bu risâlesini el-Menhecü'l-vâdih bi serbi İhkâmu abkâmi'n-nikâhb ve Sâlim b. Muhammed el-Hibşî (öl. 1330/1912) de Fütûbu'l-fettâh bi şerbi İbkâmu abkâmi'n-nikâh ismiyle şerh etmiştir.

d. el-Ecvibetü'l-'acîbe 'ani'l-esileti'l-garîbe: Eser, Melîbârî'nin yaşadığ1 dönemde fukahânın gündemini en çok meşgul eden ve popüler olan yüz seksen dokuz meseleye dair verilen fetvâdan oluşmaktadır. Melîbârî, soru şeklinde kendisine yöneltilen bu meselelerin hükümlerini, başta İbn Hacer el-Heytemî, Şemsüddîn er-Remlî, Hatîb eş-Şirbînî ve amcası Abdulazîz el-Ma'berî olmak üzere Şâfiî mezhebinde fetvâ mercii olarak bilinen dönemin on fakîhinden naklen beyân etmiştir. Nitekim Melîbârî eserin mukaddimesinde şunları kaydetmiştir: "Bu çalışma, bazı hocalarımıza ve çağdaş ulemâmıza yöneltilen ilginç bazı sorulara verilen cevaplardan ibarettir." ${ }^{\prime 7}$ Gerçekten de eser ismine uygun olarak oldukça dikkat çekici meselelere muhtevidir. ${ }^{48}$ Melîbârî, hükmü sorulan meseleyi

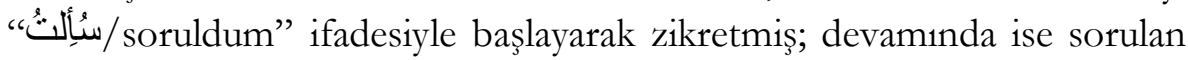

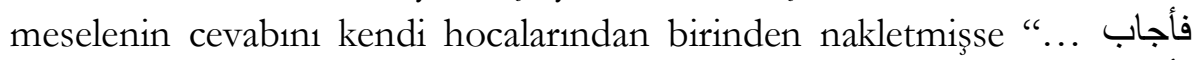

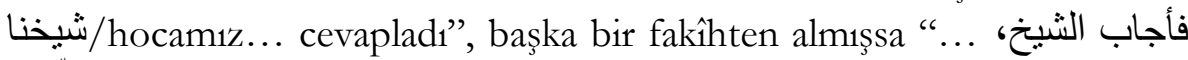
"العلّامةة" diyerek sözü edilen fakîhlerin meseleye yönelik fetvalarını nakletmiştir. ${ }^{49}$ Bunun yanı sıra nadirde olsa kendi verdiği cevaplar da

44 Ezherî, "eş-Şeyh Ahmed Zeynüddîn el-Mahdûm el-Melîbârî ve hademâtuhu”, 136.

45 Zeynüddîn Ahmed b. Muhammed el-Melîbârî, el-Menhecü'l-vâdih bi șerbi İhkâmu abkâmi'n-nikâh (Riyad: Câmi'atu Melik Suud, No: 216-5/ م.૨ ), vr. 1 a.

46 Komisyon, Indian writungs in Arabıc, 31.

47 Melîbârî, el-Ecvibetü'l-'acîbe, 2.

48 Örnek babından bk. Melîbârî, el-Ecvibetü'l- ‘acibe, 75-79.

49 Melîbârî, el-Ecvibetü'l-'acîbe, 2 vd. 


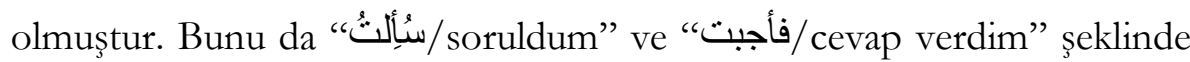
serdetmiştir. ${ }^{50}$

e. el-Fetâva'l-Hindiyye: Bazı araștırmacılar tarafından Melîbârî̀ye nispet edilen bu eserin herhangi bir nüshasına rastlanılmamıştır. ${ }^{51}$

f. Menhecü'l-vâdih bi șerbi İbkâmu abkâmi'n-nikâhb: Melîbârî’nin nikâh ve talaka dair olan İbkâmu abkâmi'n-nikâh adlı risâlesine yazdığ1 bir şerh çalışmasıdır. ${ }^{52}$

g. Fethu'l-mu 'în bi-şerbi Kurreti'l- 'ayn: Melîbârînin eserin mukaddimesinde işaret ettiği gibi bu eser, Kurreti'l- 'ayn bi mubimmâti'd-dîn adlı muhtasar metninin meramlarının açıklığa kavuşturulması ve talebelere zor gelen ifadelerinin kolaylaştırılması için ele alınmıştır. ${ }^{53}$ Eser hakkında ileride daha ayrıntılı bilgi verileceği için burada bu kısa tanımla yetineceğiz.

\section{E. Melîbârî̀nin Vefatı}

Melîbârî’nin vefat tarihiyle ilgili farklı görüşler ileri sürülmüştür. Kimi tarihçiler Melîbârî’nin vefat tarihini 987/1579 olarak vermiştir. ${ }^{54}$ Kimisi onun 991/1583 tarihinde vefat ettiğini kaydetmiştir. ${ }^{55}$ Kimisi ise Melîbârî'nin yaklaşık doksan yıl yaşadığını söyleyerek vefat tarihini 1028/1619 olarak vermiştir. ${ }^{56} \mathrm{Bu}$ son tarih daha isabetli görülmüştür. Melîbârî̀nin Chombal bölgesinde Kuncî Felî (Kungippalli)'de bulunan elMescidü’l-Kebîr civarında defnedildiği ve halen kabri bölge Müslümanları tarafından ziyaret edildiği belirtilmektedir. ${ }^{57}$

\footnotetext{
50 Melîbârî, el-Ecvibetü'l-'acîbe, 66, 75.

51 Melîbârî, Terâcimu 'ulemâi's-Şafiùyye, 87.

52 Melîbârî, Terâcimu 'ulemâi'ş-Şâfiìyye, 86.

53 Zeynüddîn Ahmed b. Muhammed el-Melîbârî, Fethu'l-mu'în bi-șerbi Kurreti'l- 'ayn, (Beyrut: Dâru İbn Hazm, 1424/2004), 31.

54 Ziriklî, el-A 'lâm, 3/64; Corcî Zeydân, Târîbu âdâbi'l-lugati'l-'arabî (Kahire: Müessesetu Hindâvî li't-Ta'lîmi ve’s-Sikâfe, 2013), 1128.

55 Melîbârî, Tubfetü'l-mücâbidîn, (tahkik edenin mukaddimesi), 5.

56 Âiletu Âlu mahdûm, www.nidaulhind.com, 93.

57 Melîbârî, Terâcimu 'ulemâi'ş-Şâfî̀yye, 93.
} 


\section{Fethu'l-Mu'în ve Şâfiî Mezhebindeki Önemi}

Bir fakîhin bağlı bulunduğu mezhepteki önemini anlamak kaleme aldığ1 çalışmalarının mezhep literatürünün gelişmesindeki katkısı ile doğru orantılıdır. Bu bağlamda Melîbârî'nin Şâfîi fikıh birikimindeki önemini anlamak bilhassa Hint Alt Kıtasında Şâfî̀ literatürünün gelişimine önemli ölçüde katkı sağlayan Fethu'l-Mu'în adlı eserini bilmekle mümkündür.

\section{A. Fethu'l-Mu'în İle İlgili Genel Bilgiler}

\section{Fethu'l-Mu'în'nin Melîbârî̀ye Aidiyeti}

Fethu'l-mu'n̂n'nin Melîbârî̀ye aidiyeti şüphe götürmeyecek kesinliktedir. Zira Melîbârî eserin önsözünde bunu şöyle izah etmiştir: "Bu çalışma Kurratu'l-'ayn metni üzerine bir şerh olup ismini fethu'l-mu'în bi serbi Kurrati'l-'ayn bi mubimmâti'd-dîn olarak koydum." ${ }^{58}$ Ayn1 şekilde Melîbârî'nin hâl tercümesini anlatan biyografik kaynaklarda da Fethu'l$m u^{\prime} i ̂ n$ 'in ona ait olduğu bilgisi mevcuttur. ${ }^{59}$ Melîbârî, bu eserini 24 Ramazan 982/1575 Cuma günü kuşluk vaktinde bitirdiğini ifade etmiştir. $^{60}$

\section{Fethu'l-Mu'în'nin Tertibi ve Kaynakları}

Yazım türü olarak eser, bir şerh çalısması olmakla beraber muhtasar bir metin formatında yazılmıştır. Gerek fikhî konular gerekse bunlara ilişkin delil ve önceki fukahânın görüşleri olsun fazla ayrıntıya girilmeden derli toplu bir şekilde ele alınmıştır. Eserin konu tertibi, bazı takdim ve tehirler hariç genel hatlarıly mezhebin temel muhtasar metinlerdeki fikıh konularının sıralaması ile aynıdır. Konu tertibi açısından eserin diğer Şâfiî muhtasar metinlerinden göze çarpan bazı farklılıklar1 şu şekildedir:

- Fethu'l-mu'în'de temizlik konusu müstakil olarak değil, namazın şartları içeresinde işlenmiştir. Temizlik meselelerinden olan "mest üzerindeki mesh"e değinilmemiştir. ${ }^{61}$

\footnotetext{
Melîbârî, Fethu'l-mu în, 31.

59 Hasenî, Nüzhetü'l-havâtır, 1, 62; Ziriklî, el-A 'lâm, 3/64

60 Melîbârî, Fethu'l-mu 'în, 673.

61 Melîbârî, Fethu'l-mu' în, 40-87.
} 
- İtikâf meselesi diğer metinlerde oruç konusunun sonunda zikredilirken Fethu'l-mu'în'de kitabın sonuna alınmıştır. ${ }^{62}$

- Diğer metinlerde korku namazı, seferi namaz, bayram namazları, güneş ve ay tutulmasının namazları ve yağmur namazı gibi meseleler "cemaatle namaz" başlığında, Fethu'l-mu' în'de bunlar "nafile namaz" başlı̆̆ında işlenmiştir. ${ }^{63}$

- Fethu'l-mu'în'de bey'/alışveriş başliğ1 altında bulunan konuların sırlamasında diğer metinlere göre bir takım takdim ve tehirler söz konusudur. ${ }^{64}$

- Ganimet ve fey' konuları diğer metinlerde bey konusunun sonunda müstakil başlıklar şeklinde işlenirken Fethu'l-mu'în'de bunlar kısa bir şekilde zakât konusu içinde ele alınmıştır. ${ }^{65}$

- Yeminler konusu Fethu'l-mu ‘în'de "şahâdât" konusunun sonunda işlenirken diğer metinlerde bu konu müstakil bir başlık olarak kazâ şahâdât konusundan önce zikredilmiştir. Yine nezir konusu Fetbu'lmu'în'de ihramın yasakları içinde zikredilirken bu konu diğer metinlerde kazâ şahâdât konusundan önce işlenmiştir. ${ }^{66}$

- Müsâkât (ürünü paylaşma esasına dayanan bağ-bahçe ortakçlluğı) konusu Fethu'l-mu ‘în'de icâre konusu içinde ele alınmıştır. Diğer metinlerde ise müsâkât müstakil olarak icâre konusundan önce işlenmiştir. ${ }^{67}$

Fethu'l-mu'în'in kaynaklarına gelince Melîbârî'nin de ifade ettiği üzere Şâfiî müteahhir fukahâsının mutemet kaynakları referans olarak alınmıştır. ${ }^{68}$ Esasen bir fikıh mezhebinde muhtasar metin yazmak o mezhebin ulaşılabilen kaynaklarının hemen hepsinin gözden geçirerek

62 Melîbârî, Fethu'l-mu'în, 666.

63 Melîbârî, Fethu'l-mu î̀, 166-170.

64 Örnek olarak bk. Ebû Zekeriyyâ Yahyâ b. Şeref b. Mürî en-Nevevî, Minhâcü’t-tâlibîn ve 'umdetü'l-muftin fi'l-fikehi (b.y.: Dâru'l-Fikr, 1425/2005), 94-204; Melîbârî, Fethu'lmu'în, 316-444.

65 Bk. Nevevî, Minhâcüt-tâlibîn, 198; Melîbârî, Fethu'l-mu'în, 256.

66 Nevevî, Minhâcü't-tâlibîn, 326-333, 333-336; Melîbârî, Fethu'l-mu 'în, 310, 660-661.

67 Nevevî, Minhâcü't-tâlibîn, 157; Melîbârî, Fethu'l-mu'în, 383.

68 Melîbârî, Fethu'l-mu 'în, 35. 
istifade etmek demektir. Dolayısıyla Melîbârî̀nin eserin telifinde birçok kaynağa müracaat etmiş olması muhakkaktır. Fakat her kaynaktan aynı derecede istifade etmiş değildir. Kendisinin de eserin mukaddimesinde ifade ettiği gibi söz konusu kaynaklardan mutemet olarak görülen çalışmalardan daha ziyade yararlanılmıștır. Bu bağlamda eserin kaynakları arasında aslan payını Melîbârî̀nin ilmî şahsiyetinin teşekkülünde en çok etkisi bulunan İbn Hacer el-Heytemînnin şu fikıh eserleri olmuştur: Tubfetü'l-mubtâc bi-şerbi'l-Minhâc, Fethu'l-cevâd fì șerbi'l-Irşâd, el-İmdâd fì șerbi'lİrşâd, el-Î'âb fî şerbi'l-'Abâb ve el-Fetâva'l-fikhiyyetül-kü̈brẩ. Melîbârî eserde İbn Hacer'e atıf yaparken genelde “شيخنا/hocamız” ifadesini kullanmıştır. Eserde mutlak olarak zikredildiğinde bu ifadeden İbn Hacer kastedilir. ${ }^{69}$ Yine İbn Hacer'in eserleri kadar olmasa da Melîbârî̀nin şu kaynaklardan da önemli ölçüde yararlanmıştır: Ebû Zekeriyyâ Yahyâ b. Şeref enNevevînin (öl. 676/1277) el-Mecmû̀ sserbu'l-Mübezzęb ve Ravaatüt-tâlibin ve 'umdetü'l-müttakin'i; Cemâlüddîn (İzzüddîn) Yûsuf b. İbrâhîm elErdebîlî̀nin (öl. 779/1377 [?]) el-Envâr li-a 'mâl ('amel)i'l-ebrâr'1; Zekeriyyâ b. Muhammed b. Ahmed es-Süneykî el-Ensârî̀nin (öl. 926/1520) Fethu'lvehbâb bi-șerbi Menheci't-tullâb ve Esne'l-metâlib şerbu Ravįi't-tâlib'i. Ayrica Melîbârî'nin eserde kaynak belirtmeksizin atıfta bulunduğu birçok fakîh daha bulunmaktadır. Bunlardan en çok atıf yapılanların isimlerini şöyle sıralayabiliriz: Ebû Hâmid Muhammed b. Muhammed b. Muhammed elGazzâlî (öl. 505/1111), Takıyyüddîn Osmân b. Salâhiddîn Abdirrahmân b. Mûsâ eş-Şehrezûrî (öl. 643/1245), İzzüddîn Abdülazîz b. Abdisselâm b. Ebi'l-Kāsım es-Sülemî (öl. 660/1262), Necmüddîn Ahmed b. Muhammed b. Alî İbnü’r-Rif'a el-Ensârî (öl. 710/1310), Takıyyüddîn Alî b. Abdilkâfî b. Alî b. Temmâm es-Sübkî (öl. 756/1355), Şihâbüddîn Ahmed b. Hamdân b. Ahmed el-Ezrâî (öl. 783/1381), Bedrüddîn Muhammed b. Bahâdır b. Abdillâh el-Minhâcî ez-Zerkeşî eş-Şâfiî (öl. 794/1392) Cemâlüddîn Abdürrahîm b. el-Hasen b. Alî el-İsnevî (öl. 772/1370), Ebü'l-Fazl Abdurrahmân b. Ömer b. Reslân el-Bulkīnî (öl. 824/1421) ve Ebü'z-Ziyâ Abdurrahmân b. Abdilkerîm b. İbrâhîm elGaysî ez-Zebî̀î (öl. 975/1568).

69 Melîbârî, Fethu'l-mu în, 39, 49, 50, 58 vd. 


\section{B. Fethu'l-Mu'în'in Şâfiî Mezhebindeki Önemi}

\section{Görülmesi \\ 1. Fethu'l-Mu'în'in Mezhep İçinde Mutemet Kaynak Olarak}

Şâfiî muhitinde gerek kaynak olarak kullanılması gerekse fetvâ için müracaat edilmesi hususunda olsun Râfiî ve Nevevînin (şeyhayn) eserleri esas alınmaktadır. Şihâbuddîn er-Remlî bu konuda şunları aktarmaktadır: "Şeyhayn'ın mezhep içindeki çalışmaları kayda değerdir. Bu sebeple de ilmiyle amel eden (Şâfiî) âlimler, bu iki fakîhin görüşlerine itimat ederek delillerle takviye etmektedirler. İhtilafa düştükleri konularda ise Nevevî’nin görüşü ile amel etmektedirler." ${ }^{\text {70 }}$ Nevevî̀den sonra Şâfî̀ fukahâsı, fikıh anlayışını onun eserlerinde yer alan görüşlere göre şekillendirmeye çalısmış ve onu izleyen merhalede Şâfî̀ fikıh literatürü onun eserleri ekseninde gelişimini sürdürmüştür. Müteahhir Şâfiî fukahâsından bu döneme damgasını vuran ise İbn Hacer el-Heytemî ve Şemseddin er-Remlî olmuştur. Nitekim İbn Hacer ve Remlî Nevevî'den kendi dönemlerine kadar Şâfî̀ fikıh birikimini ayıklayıp Tubfetül-mubtâc ve Nihâyetül-mubtâc adlı eserlerinde derlemişlerdir. ${ }^{71}$ Mezhebin ikinci şeyhayn'i olarak niteleyebileceğimiz İbn Hacer ve Remlî'den sonra Şâfiî ulemâsının çoğunluğu, İbn Hacer el-Heytemî’nin takrir ettiği görüşler ile amel etmektedirler. Misır yöresi Şâfiî müntesipleri ise Remlînnin takrir ettiği görüşleri esas almaktadırlar. ${ }^{72}$

Melîbârî, hem İbn Hacer'in talebesi olması hem de onun fikıh anlayışının hâkim olduğu bölgede yetişmiş bir fakîh olması hasebiyle fikhî çalışmalarında İbn Hacer'in eğilimini esas almıştır. Buna binaen de Melîbârî’nin fikhî düşünceleri özellikle sözü edilen bölgelerin fakîhleri tarafından muteber görülmüş ve onun fikıh çalışmaları mutemet olarak

70 Şihâbüddîn Ahmed b. Ahmed b. Hamza er-Remlî el-Menûfî el-Enșârî, Fetâva'rRemlî, (b.y.: el-Mektebetü'l-İslâmiyye, tsz.), 4/262; Mehmet Aziz Yaşar, Memlûkeler döneminde fikęh siyaset ilişkisi (Ankara İlâhiyât Yayınları, 2020), 98-99.

71 Bilal Aybakan, "Şâfiî Mezhebi”, Türkiye Diyanet Vakfı İslâm Ansiklopedisi (Ankara: TDV Yayınları, 1999), 38/239.

72 Şemsüddîn Muhammed b. Süleymân el-Kürdî el-Medenî, el-Fevâ'idü'l-medeniyye fì-men yüftâ bi-kavlihî min e'immeti'ş-Şafi 'iyye (müte ahhirir's-sâdeti'ş-Şâfi 'îyye) (Dimaşk: Dâru Nûru'ṣ-Ṣabâh, 1432/2011), 38; Aybakan, "Şâfiî Mezhebi”, 34/242; Mahsum Aslan, İbn Hacer el-Heytemî İle Semsuddîn er-Remlî ve İhtilaf Sebepleri (Diyarbakır: Dicle Üniversitesi, Doktora Tezi, 2018), 139-144. 
kabul edilmiştir. Bu çerçevede onun fikhî birikimini en iyi şekilde yansitan Fethu'l-mu'în adlı eseri büyük bir teveccüh görmüss ve birçok fakîh tarafindan methedilmiştir. Bu cümleden olarak Şair ve âlim Ferîd b. Muhyiddîn el-Berberî (öl. 1300/1883) Fethu'l-mu'în'in önemini şu beyitlerle anlatmıştır:

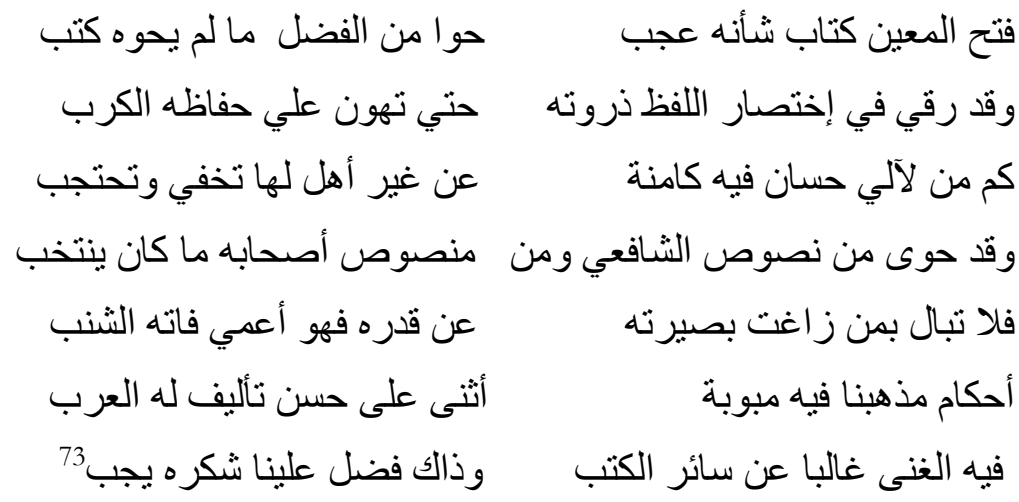

Esasen bir eserin kıymet-i ilmiyesini gösteren amillerin başında, sonraki âlimler tarafindan güvenilir kaynak olarak addedilip pratik dinî ihtiyaçlarının çözümü için ona müracaat edilmesi hususu gelmektedir. Bu anlamda Fetbu'l-mu'în müteahhir Şâfiî fakîhleri tarafindan güvenilir bir kaynak olarak telakki edilmiş ve onlar, gerek kendi görüşlerinin desteklemesi için gerekse fetvâ ve kazâ işlemlerinde olsun onu referans kaynak olarak kullanmışlardır. Bu bakımdan da Fethu'l-mu'în uzun bir zaman diliminde Şâfîi müntesiplerinin önemli bir kısmı için başucu esere konumunda olmuştur. Fethu'l-mu 'în'i kendi eserlerinde referans olarak kullanan âlimler arasinda Tühfetü'l-mubtâc'in muhaşşisi Abdulhamîd eşŞirvânî (öl. 13001/1884), Muhammed b. Ömer Nevevî el-Câvî,

\footnotetext{
73 Şanı yücedir Fethu'l-muı̂n’ in başka kitabın sahip olmadığı meziyete sahiptir o

Oldukça muhtasar ifadeleri kolayca ezberlenebilir niteliktedir o

Güzel nüktelerle doludur o ancak ehil olanlar görebilir onları İçerir İmam Şâfî̀'nin ve ashabının seçkin naslarını

Onun kadrini idrak edemeyen kördür, göremez güzelliklerini

Tasnif eder mezhebimizin fikhını güzel telifini metheder Araplar

İhtiyaç birakmaz diğer kitaplara $\mathrm{Bu}$, bir lütuftur şükür gerekir bize.

Ezherî, "eş-Şeyh Ahmed Zeynüddîn el-Mahdûm el-Melîbârî ve hademâtuhu”, 139.
} 
Abdurrahman Bâ 'Alevî (öl. 1320/1902) ve Şeyh 'Alevî b Muhammed esSekkâf1 (öl. 1335/1917) saymamız mümkündür. ${ }^{74}$ Aynı şekilde günümüz ilim dünyasında da Fethu'l-mu'în'e bir rağbet olduğuna vakıf olmaktayız. Nitekim birçok muasır fakîh, fikıh ansiklopedileri ve fetvâ kurulları da Fethu'l-mu'în'i referans kaynak olarak kullanmışlardır. Bunlardan bazılarını şöyle sıralayabiliriz: Vehbe b. Mustafa ez-Zuhaylî, ${ }^{75}$ Ebû Ömer Dübyân b. Muhammed ed-Dübyân; ${ }^{76}$ Komisyon, el-Mevsû'atü’l-fikiyyetü’lKuveytiyye, Komisyon, Mevsû'atü'l-icma' fi'l-fikhi'l-İslâmî; Fetâva'şşebeketi'l-İslâmiyye, Fetâvâ ve istişârât mavki'i'l-İslâm el-yevm.

\section{Fethu'1-Mu'în'in Ders Kitabı Olarak Okutulması}

Fethu'l-mu'în' in Şâfiî mezhebindeki konumunu gösteren hususların belki de en önemlisi onun ders kitabı olarak okutulmuş olmasıdır. Fethu'l$m u^{\prime} i n$ ' in eski dönemlerde klasik eğitim sistemiyle tedrisat yapan birçok medrese ve ders halkalarında okutulduğu kaydedilmektedir. Fethu'lmu'în'in başta Haremeyn-i Şerfiyn olmak üzere hicaz bölgesinin birçok yerinde, Yemen, Suriye, Hint alt kitasının güney sahili, Endonezya, Somali ve Malezya gibi İslâm âleminin geniş bir coğrafyasında, uzun bir süre ders olarak okutulmuştur. Zira Fethu'l-mu‘în birçok çalışmaya konu olması ve bu çalş̧maları yapan âlimlerin hemen hepsinin onu kendi talebelerine okuttuğuna işaret etmesi onun çokça okutulduğunun bariz örnekleridir. ${ }^{77}$

Fethu'l-mu'în popülaritesi günümüzde de sürmektedir. Zira günümüz Şâfîi fukahâsı ona büyük bir teveccüh göstermekte ve onun okunmasını ve okutmasını önemle tavsiye etmektedirler. Nitekim son

74 Bk. Abdulhamîd eş-Şirvânî Havâşi'ş-Şirvânî (Tubfetü'-lmubtac ile birlikte) (Mısır: elMektebetü't-Ticâriyye, 1357/1987), 2/405, 431; 7/198, 201, 207, 217, 218, 224, 235; Muhammed b. Ömer Nevevî el-Câvî, Kâssifetü's-secâ şerbu Sefineti’n-necâ (Beyrut: Dâru İbn Hazm, 1432/2011), 228, 288, 378, 409; Abdurrahman b. Muhammed b. Hüseyin Bâ 'Alevî, Bugigetül-müsterşidîn fî̀ telhis fetâvâ ba'di'l-eimmeti mine'l-muteabhirîn (Terîm: Dâru'l-Fakîh li’n-Neşri ve't-Tevzî', 1430/2009), 1/381.

75 Vehbe b. Mustafa ez-Zuhaylî, el-Fıkhü'l-İslâmî ve edilletühu (Suriye: Dâru'l-Fikr, tsz.), 4/2640, 2645, 2650.

76 Ebû Ömer Dübyân b. Muhammed ed-Dübyân, el-Mu'âmelâtü'l-mâliyye esâleten ve mu'âsere (Riyad: Mektebetü'l-Melik Fehd el-Vataniyye, 1432/2011), 2/68; 7: 163, $179,363$.

77 Dimyâtî, I'ânetü't-tâlibîn, 1: 13; es-Seyyid 'Alevî b. Seyyid Ahmed es-Sekkâf, Terşîhu'lmüstefídîn bi tevsibi Fethu'l-mu 'în, 2. 
dönem âlimlerinden fakîh Muhammed eş-Şukayr'in bu meyandaki şu ifadeleri önemlidir: "İbn Hacer'den ilim tahsil eden âlimlerden biri Zeynüddîn el-Melîbârî'dir. O, zayıf görüşlerden hali, faydalı, muhtasar bir kitap telif etti. $\mathrm{Bu}$, fetvâ için elverişli bir kitaptır.... Ulemâ tarafından kabul gördü ve okunması tavsiye edildi. 'Allâme Molla Ramazan, birçok âlim yetiștiren 'Allâme Hasan Habenneke ve Şeyh Mahmud el-Habbâl bu kitabı okuyan ve okunmasını teşvik eden önemli simalardandır." 78 Fetbu'lmu'în günümüzde başta Hindistan'ın güney sahil bölgesi olmak üzere Şâfî̀ mezhebinin hâkim olduğu muhitlerde klasik eğitim veren birçok medrese ve ders halkaları ile birlikte modern eğitim sistemiyle faaliyet yürüten bazı üniversite, fakülte, enstitü ve diğer dinî eğitim öğretim kurumlarında ders müfredat1 olarak okutulmaktadır. Fethu'l-mu'în'in Hindistan'ın Tâmil Nâdu vilayetinde bulanan el-Bâkiyâtü's-Sâlihât Fakültesi, Kerala vilayetinde bulunan el-Câmi'atü'n-Nûriyetü'l-'Arabiyye ve Câmi'atu Dâra'l-Hüde'l-İslâmiyye üniversitelerinde ve bu kurumların sistemiyle din eğitimini veren Hindistan'ın daha pek çok külliye, enstitü ve diğer dinî eğitim merkezlerinde ders kitabı olarak okutulduğu bilinmektedir. Aynı şekilde Terîm ve Hadramevt başta olmak üzere Şâfiî mezhebinin hâkim olduğu Yemen'in bazı kentlerinde ile Somali ve Sri Lanka'da bulunan dinî eğitim kurumlarının birçoğunda ders olarak talebelere okutulmaktadır. ${ }^{79}$ Yine Fethu'l-mu'în'in Irak Kürt bölgesinde ve Türkiye'de klasik tedrisat yapan bazı medreselerde de okutulmaktadır. Fethu'l-mu'în'in Kahire'de bulunan Câmi'u'l-Ezheri'ş-Şerîf ve Şam'da bulunan Câmi'u'l-Emevî gibi büyük ve merkezi camilerde öteden beri ders halklarında okutulduğu belirtilmektedir. ${ }^{80}$ Ayrica Fethu'l-mữ̂n, Muhammed eş-Şukayr, Rüşdî Selîm el-Kalem ve Hüseyin Abdullah el-'Alî gibi çağdaş birçok âlim tarafindan ders olarak verilmiş ve bu dersler video kayıt sistemiyle kayıt altına alınmıştır. Bu kayıtlara internet üzerinden erişilebilmektedir. ${ }^{81}$

\footnotetext{
78 Melîbârî, Fethu'l-mu î̀, (tahkîk edenin mukaddimesi), 3.

79 http://www.alhabibomar.com/Lessons.aspx?SectionID=7; http://rebatalfateh1030.blogspot.com/, erişim tarihi: 24.7.2020.

80 https://www.nidaulhind.com/2017/04/blog-post_21., erişim tarihi, 23.6.2020.

81 https://www.nidaulhind.com/2017/04/blog-post_21.; http://www.awqafdamas.com/?page $=$ search; erişim tarihi: 22.6.2020;
} 


\section{Fethu'l-Mu'în' in Üzerine Yapılmış Çalışmalar}

Fethu'l-mu'în'in Şâfî̀ fikı birikimindeki öneminin en önemli göstergelerinden biri de sonraki fakîhler tarafindan çalışma konusu yapılmış olmasıdır. Nitekim Fethu'l-mu'în, telif edildikten sonra birçok fakîhin teveccühüne mazhar olmuş ve birçok çalışmaya konu edilmiştir. Bu bakımdan da Şâfiî fikıh literatürünün gelişiminde muazzam bir katkı sunmuştur. Bu çalışmalar şerh, haşiye, talik, nazım ve tercüme gibi farklı türlerden oluşmaktadır. Bu nedenle burada bu çalışmaların her bir türünü ayrı başlık altında zikredeceğiz.

\section{a. Fethu'1-Mu'în'in Üzerine Yapılmış Şerh Çalı̧̧ması}

İslâm telif geleneğinde şerh çalışması genellikle muhtasar metinler üzerine yapılmaktadır. Şerh türü çalışmalarda muhtasar metnin bütün ifadeleri açıllanmaktadır. Bunun yanı sıra bu tür teliflerde muhtasar metinlerde eksik bırakılan yerler tamamlanmakta, içinde bulanan hatalar düzeltmekte ve örneklerle muhteva zenginleştirilmektir. ${ }^{82} \mathrm{Bu}$ yazım türünden Fethi'l-mu'în üzerine yapılmış şu çalışma bulunmaktadır: Şerbün 'alâ Fethi'l-mu'în. Bu şerh, Melîbârî̀nin torunu 'Allâme Zeynüddîn elMahdûmü'l-Ehîr el-Fennânî (öl. 1305/1888) tarafindan kalem alınmıştır. Üç cüz şeklinde telif edilen bu çalışma henüz ilim dünyasına kazandırılmamıștır. ${ }^{83}$

\section{b. Fethu'l-Mu'în'in Üzerine Yapılmış Hâşiye Çalışmaları}

Hâşiye, bir eserin sayfa boşluklarına ilâve edilen açıklayıcı ve tamamlayıcı bilgileri içeren notlardır. Bu tip çalışmalar genellikle muhtasar metinlere yazılmış şerhler üzerine yapılmaktadır. Hem şerhte hem de metinde bulunan kapalı ifadeleri ya da onlarda geçen özel isim, âyet, hadis, şiir gibi hususları açıklamaktadır. ${ }^{84}$ Fetbu'l-mu'în'in üzerine yapılmış hâşìye türü eserler şunlardır:

1. Alî b. eş-Şeyh el-'Ârif Billah Abdurrahman en-Nakşebendî etTânûrî el-Melîbârî (öl. 1178/1764) Tensîtu’l-mutâli ‘̂n 'alâ bâşìyeti Fetbi’l-

82 Sedat Şensoy, "Şerh", Türkiye Diyanet Vakfi İlâm Ansiklopedisi (Ankara: TDV Yayınlar1, 2010), 38/555.

83 Melîbârî, Terâcimu 'ulemâi'ş-Şâfî̀yye, 89.

84 Tevfik Rüştü Topuzoğlu, "Hâşiye", Türkiye Diyanet Vakefi İslâm Ansiklopedisi (Ankara: TDV Yayınlan1, 1997), 16/419. 
mu'în. Eser tamamlanmamıştır. Mevcut kısmı basılmıştır. Fethu'l-mu'în'in ilk hâşiyesi olarak bilinmektedir. ${ }^{85}$

2. Alî b. Ahmed b. Saî̀d Bâsabrayn (öl. 1304/1887): I'ânetü’lmüsta'în 'alâ Fetbi'l-mu'în. ${ }^{86}$

3. Osmân b. Muhammed Şetâ el-Bekrî ed-Dimyâtî (öl. 1310/1893), I'ânetü't-tâlibîn 'alâ halli elfâzi Fetbi'l-mu'în. Fetbi'l-mu'în hâşiyeleri arasında en büyük, en faydalı ve ifade açısından en akıcı hâşiye olarak bilinmektedir. Birçok yerde Fetbi'l-muî̀n bu eser ile birlikte okutulmaktadır. $^{87}$ Eser Abdullah el-Mevlevî el-Melîbârî tarafindan Malâbâr'ın yerel dili olan Maleyâlem'e tercüme edilmiştir.

4. Ahmed eş-Şîrâzî en-Nâdâfermî el-Melîbârî (öl. 1326/1908): Hâsiyetün 'alâ Fetbi'l-mu'în. Eser mahtût olup bir nüshası Hindistan'ın Nâdâferm şehrinde bulunan el-Câmi'u'l-Kebîr kütüphanesinde kayıtlidır. $^{88}$

5. es-Seyyid 'Alevî b. Seyyid Ahmed es-Sekkâf (öl. 1335/1917): Terşî̉u'l-müstefídin bi tevsibi Fetbi'l-mu 'în. ${ }^{89}$

6. eş-Şeyh Mihrân Musliyâr en-Nermertûrî el-Melîbârî (öl. 1403/1983) ve 'Allâme Ebû Bekir et-Tânûrî el-Melîbârî (öl. 1415/1994) Hâsisiyetu fethi'l-mülbim 'alâ Fetbi'l-mu î̀n.

\footnotetext{
85 Muhyisünne Abdulkādîr b. Muhammed el-Melîbârî, Tabkîk̂u'l-matleb bi ta'rîfi mustalabi'l-mezheb mezhebi'l-imâmi'ş-Şâfî̀ (Beyrut: Dâru'l-Kütübi'l-İlmiyye, tsz.), 241.

86 Ziriklî, el-A 'âm, 4: 260.

87 Ömer Rizâ Kehhâle, Mu'cemü'l-mü'ellifìn: Terâcimü muṣannifi'l-kütü̈bi'l-'Arabiyye (Beyrut: Dâru İhyâi't-Türâsi'l-'Arabî, tsz.), 6/270.

88 Melîbârî, Terâcimu 'ulemâi's-Şafî̀yye, 189.

89 Kehhâle, $M$ u'cemü'l-mü'ellifin, 6: 295.

90 https://www.nidaulhind.com/2017/04/blogpost_21.html?fbclid=IwAR3SkoHrhukI0HlO9jWP3hPLJCK17OYFNIAnHIYuBJ uC5uuQ96bGRu2vqC0, 4.7.2020.
} 


\section{c. Fethu'l-Mu'în'in Üzerine Yapılmış Ta'lîk ve Takrîr Çalışmaları}

Ta'lîk, zor bir metnin daha iyi anlaşılabilmesi ya da metin sahibinin görüşlerinin tenkidi için sayfaların kenarına veya alt kısımlarına yazılan ilave ve notlardır. Takrîr ise bir eserde bulanan bir meseleyi derinden inceleyip tahkikini yapmak ve açıklamaktır. ${ }^{91}$ Fethi'l-mu' in üzerine yapılmış bu tür çalışmaları şöyle sıralayabiliriz:

1. Ahmed b. Abdilazîz el-Mahdûm el-Fennânî (öl. 1277/1861): Ta'likeun 'alâ Fethi'l-mu în. ${ }^{92}$

2. Ahmed es-Sagî̀r b. Muhammed el-Bilinkûtî el-Melîbârî (öl. 1341/1923): Ta'lîkun kebirun 'alâ Fethi'l-mu 'in. ${ }^{93}$

3. Şeyh Küncu Muhammed Musliyâr b. eş-Şeyh el-'Allâme Ahmed Kûtî Musliyâr el-Melîbârî (öl. 1352/1934): Takrîâtün 'alâ Fethi'l$m u^{\text {' }} \hat{n} .^{94}$

4. Şeyh Küncu Ahmed Musliyâr el-İrumbâlşî̂̂ (öl. 1364/1945): Ta lîkâtün 'alâ Fethi'l-mu 'în. ${ }^{95}$

5. Şihâbuddîn Ahmed Kûyâ eş-Şâliyâtî (öl. 1374/1955): Takrîrün 'alâ Fethi'l-mu î̀n.

6. eş-Şeyh Muhammed Musliyâr b. Sûfî Musliyâr elKerinkeffârâvî el-Melîbârî (öl. 1405/1985): Takrîrâtün 'alâ Fetbi'l-mu' in.$^{97}$

7. eş-Şeyh Ebî Ahmed Musa el-Berdelî (öl. 1393/1973): Takrîrâtün 'alâ Fethi'l-mu în. ${ }^{98}$

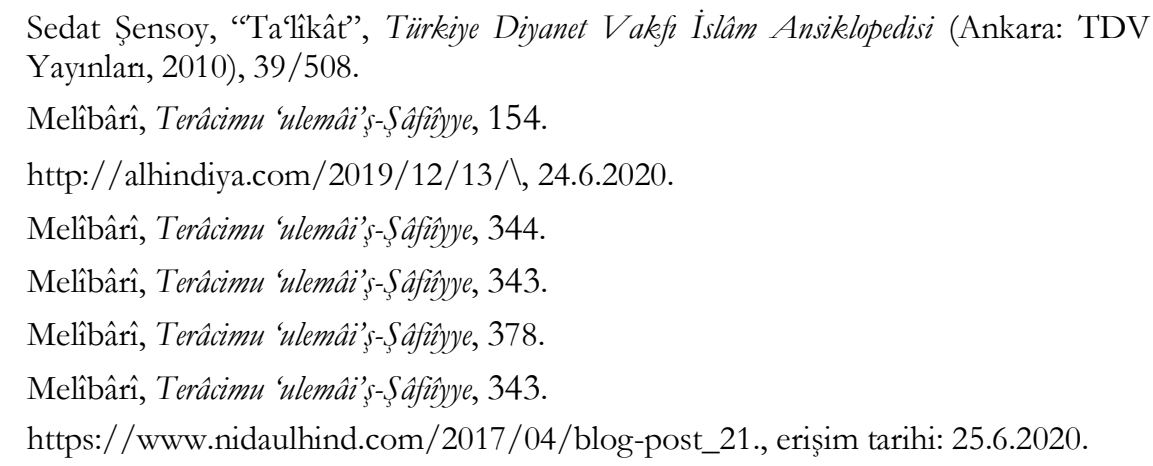


8. eş-Şeyh el-'Allâme Küncâmû el-Feydî el-Melîbârî: Ta 'likâatün 'alâ Fetbi'l-mu' in. ${ }^{99}$

\section{d. Fethu'l-Mu'în'in Üzerine Yapılmış Diğer Çalışmalar}

1. Şeyh Muhammed Musliyâr b. Hasen el-Arakkelî el-Vadânfellî: Manzûmetu ferâizi Fetbi'l-mu'în. Eserde Fetbi'l-mu'în'in ferâz bölümü nazmedilmiştir. ${ }^{100}$

2. Şeyh Abdurrahman Bâvâ el-Melîbârî: Hullâsatül-fıkehîl'İslâmî (Hullâsatu Fethi'l-mu 'în). Eser Fetbi'l-mu î̀n'n özetidir. Üç cilden ibaret olan bu eser, önce birinci cildi Hullâsatu Fethi'l-mu în adıyla basılmıştır. Daha sonra eser bir komisyon tarafindan gözden geçirilmiş ve her üç cildi Hullâsatül-fikkhîl-islâmî ismiyle yayınlanmıştır.

3. Şeyh Kunc Musliyâr el-Melîbârî: el-Mubimme fì beyân'l-eimmeti'lmękềrin fî Fethi'l-mu'în. Eserde Fethi'l-mu'în'de geçen âlimlerin biyografileri ele alınmıştır. ${ }^{101}$

\section{d. Fethu'l-Mu'în'in Üzerine Yapılmış Tercüme Çalışmaları}

Yukarıda zikrettiğimiz Fethu'l-Mu'în ile ilgili çalışmalar, genel itibariyle ilim erbabına yönelik ilmî çalışmalardan ibarettir. Bunun yanı sıra Şâfiî mezhebine mensup Müslüman halkının pratik dinî ihtiyaçlarının çözümü için Fethu'l-Mu`inn, başta Hint Alt Kıtasının yerel dilleri olmak üzere Türkçe, İngilizce, Malayalam, Kannada, Endonezya ve Malezya gibi dillere de tercüme edilerek büyük bir okuyucu kitlesinin istifadesine sunulmuştur. ${ }^{102}$

\section{Sonuç}

Hint Alt Kitası erken dönemlerden itibaren İslâm dini ile tanışmıştır. İslâm'ın kıtada yayılması ise genel olarak fetih hareketlerinin ve Müslümanların irşat faaliyetlerinin etkili olduğu görülmektedir. İslâm'ın kabulüyle birlikte kıtada fikıh mezhepleri de yayılmıştır. Bu

\footnotetext{
99 https://www.nidaulhind.com/2017/04/blog-post_21., erişim tarihi: 25.6.2020.

100 Abdullah Muhammed el-Hubeyșî, Câmi'u'ş-şürûbi ve'l-havâş̧̂̀ (Ebu Dabi: elMacma'u's-Sikâfî, 1425/2004), 2/1350.

101 Ezherî, “eş-Şeyh Ahmed Zeynüddîn el-Mahdûm el-Melîbârî ve hademâtuhu”, 124.

102 Ezherî, “eş-Şeyh Ahmed Zeynüddîn el-Mahdûm el-Melîbârî ve hademâtuhu”, 138.
} 
bağlamda kıtanın kuzey ve orta kesiminde Hanefillik hâkim mezhep konumunda olmuş, güney sahil şeridinde ise Şâfiî fikıh anlayışı benimsenmiştir. Kıtada fikhî mezheplerin yayılışıyla beraber mezhep eksenli çok sayıda medrese kurulmuş ve birçok fakih yetişmiştir. Kıtanın yetiştirdiği mümtaz fakîhlerinden biri, ilim ve irfan ailesi olarak şöhret bulan Mahdûm ailesine mensup Zeynüddîn Ahmed el-Melîbârî̀ eşŞâfî̀'dir.

Melîbârî, ilk ilim tahsilini kendi memleketinde görmüștür. Daha sonra Mekke'ye gitmiş ve burada bulunan dönemin meşhur Şâfî̀ fakihlerinden ilim tahsili ile birlikte tasavvufun adap ve ilkelerini öğrenmiştir. İlim ve tasavvuf icazetlerini aldıktan sonra memleketine dönmüş ve burada otuz ylldan fazla kesintisiz bir şekilde irşat ve tedrisat faaliyetlerinde bulunmuştur. Bunun yanı sıra Melîbârî, o dönemde Hindistan'da sömürgecilik faaliyetlerinde bulunan gayr-i müslim diş güçlere karşı Hint toplumunu bilinçlendirmiş ve toplumun onlara karş1 tavır almasında önemli bir rol oynamıştır. Aynı zamanda Melîbârî toplumun dinî meselelerinin çözümü için de uğraşmış ve bu konuda özellikle Şâfiî müntesiplerinin müstağni kalamayacağı fetvâ çalışmaları yapmıştır. Onun fetvâları hem bölgede hem bölge dışında büyük bir itibar görmüştür.

F1khî yönüyle öne çıkan Melîbârî bu alanda kayda değer çalışmalar yapmıştır. Onun bu çalışmaları ise klasik Şâfiî fikılh geleneğinin bir devamı niteliğindedir. O, fikhî faaliyetlerini geleneksel Şâfiî fikıh ekseninde gerçekleştirmiş ve mezhep içindeki yerleşik görüşün dışına pek çıkmamıştır. $\mathrm{Bu}$ yüzden onun fikhî tercihlerinin geneli mezhep içi görüşler şeklinde olduğu ifade etmek mümkündür. Ancak Melîbârî̀nin gerek fikhî meselelere ilişkin mezhep imamlarının görüşlerini sistematik bir biçimde sunup temellendirmesinden gerekse kaleme aldığı fikhî çalışmalar ile Şâfiî literatürünün gelişmesinde oynadığ1 önemli rolden ötürü olsun, mezhep içinde kendisinden çokça söz ettirmiş ve mezhepte önemli bir yer meşgul etmiştir.

Melîbârî̀nin fikıh alanında telif ettiği bu çalışmalardan en çok ses getiren ise kendi telifi olan Kurratu'l-'ayn muhtasar fikıh metnine yazdığ1 Fetbu'l-mu‘în adlı şerh çalışmasıdır. Telifinden itibaren büyük bir teveccüh gören eserin ünü, müellifinin ününü geçmiş ve müellif onun ismiyle anılır olmuştur. Melîbârî, Şâfiî muteahhirîn temel fikı metinlerinden istifadeyle hazırladığı eserde mezhepte mutemet kabul edilen iki eğilimden biri olan İbn Hacer el-Haytemî’nin eğilimini benimsemiştir. Dolaysıyla eser, 
mezhep içerisinde İbn Hacer'in fikıh anlayışını benimseyen bölgelerde daha fazla itibar görmüştür. Nitekim Fethu'l-mu'în bu bölgelerde, eski dönmelerde medrese ve ders halkalarında yoğun bir şekilde okutulduğu gibi günümüzde de hem klasik medrese usûlü hem de modern sistem ile ders veren birçok dinî eğitim kurumlarında derse kitabı olarak okutulmaktadır. Keza eser, gerek ilmî çalısmalarda gerekse fetvâ vermede olsun Şâfîi müntesipleri arasında mutemet olarak kabul edilmiş ve müracaat edilen temel kayanlar arasında yer almıştır. Zaten eser üzerinde birçok hâşiye, ta'lîk, takrir, nazım, ihtisar, şerh gibi çalısmaların yapılması ve Hindistan'ın birçok yerel dilleri ile birlikte Türkçe, Endonezce, Malayca ve İngilizceye tercüme edilmesi onun kıymet-i ilmiyesini ortaya koymaktadır. Bu bakımdan da Melîbârî'nin bu eseriyle Şâfî̀ fikıh birikiminin zenginleşmesinde önemli bir katk1 sunduğunu ifade etmek mümkündür. 


\section{KAYNAKÇA}

'Avvâdî, Yusûf Muhammed 'Abduh. "el-'Allâme Abdurrahman b. Ziyâd el-Maksarî ve cühûdu'l-ilmiyye ve eseruhu 'alâ talebeti'l-'ilmi ve'lmuctame"'. Mecelletu Câmi'ati'l-Medinneti'l-'Alemiyye. 17 (2016), 137175.

'Ayderûs, Muhyüddîn 'Abdulkādir b. Abdillah. en-Nûru's-sâfir 'an abbâri'lkarni’l-âsisir. Beyrut: Dâru'l-Kütübi'l-İlmiyye, 1405/1985.

Aslan, Mahsum. İbn Hacer el-Heytemî İle Şemsuddîn er-Remlî ve İbtilaf Sebepleri. Diyarbakır: Dicle Üniversitesi, Doktora Tezi, 2018.

Bâ 'Alevî, Abdurrahman b. Muhammed b. Hüseyin. Buggyetü'l-müsterșidîn fî̀ telhis fetâvâ ba'di'l-eimmeti mine'l-muteabhirîn. 2 Cilt. Terîm: Dâru'lFakîh li’n-Neșri ve't-Tevzî́, 1430/2009.

Bağdatlı, İsmâil Paşa. Hediyyetü'l-ârifinn. 2 Cilt. İstanbul: Matba'atü'lBehiyye, 1370/1951.

Bilal Aybakan, "Şâfîi Mezhebi", Türkiye Diyanet Vakfı İslâm Ansiklopedisi. 38/223-233. Ankara: TDV Yayınları, 1999.

Câvî, Muhammed b. Ömer Nevevî. Kâsisfetü's-secâ șerbu Sefineti'n-necâ. Beyrut: Dâru İbn Hazm, 1432/2011.

Kâtib Çelebî, Hacı Halife Mustafa b. Abdullah. Süllemü'l-vüsûl ilâ tabakâti'l-fubûl. Thk. Mahmud Abdulkādir Arnaût. 6 Cilt. İstanbul: Mektebetu İrsîkâ, 1431/2010.

Dimyâtî, Osman b. Muhammed Şetâ el-Bekrî. I'ânetuìt-tâlibîn 'alâ balli elfâzi Fethu'l-mu'în. 4 Cilt. B.y.: Dâru'l-Fikr li't-Taba'ati ve'n-Neşr ve't-Tavzî', 1418/1997.

Dübyân, Ebû Ömer Dübyân b. Muhammed. el-Mu'âmelâtü'l-mâliyye esâleten ve mu'âsere. 20 Cilt. Riyad: Mektebetü'l-Melik Fehd el-Vataniyye, $1432 / 2011$.

Ezherî, Rafîk Abdulberr el-Vâfî. "eş-Şeyh Ahmed Zeynüddîn el-Mahdûm el-Melîbârî ve hademâtuhu”. Sikâfetü'l-Hinde Mecelletün İlmiyyetün Sikâfiyyetün. 64/3 (2013), 118-169.

Hâkim, Muhammed b. Abdillâh b. Muhammed el- en-Nîsâbûrî. elMüstedrek 'ale'ș-Sabîhayn (el-Müstedrek 'ale's-Seyhayn). Thk. Mustafa 
'Abdulkādir 'Atâ. 4 Cilt. Beyrut: Dâru'l-Kütübi'l-İlmiyye, 1411/1990.

Hasenî, Abdülhayy b. Fahriddîn b. Abdilalî. Nüzhetü'l-havâter ve behcetü'lmesâmi` ve'n-nevâzır. 8 Cilt. Beyrut: Dâru İbn Hazm, 1420/1999.

Hubeyşî, Abdullah Muhammed. Câmi'u'ş-š̈ruhbi ve'l-havâş̂̀. 3 Cilt. Ebu Dabi: el-Macma'u's-Sikâfî, 1425/2004.

Hüsnî, 'Abdulhay). es-Sikâfetül-İslamiyye fi'l-Hind. Kahire: Müessesetu Hindâvî li’t-Ta'lîm ve’s-Sikâfe. 2015.

İbn Keșîr, Ebu'l-Fidâ İsmâill b. Ömer. el-Bidâye ve'n-nibâye. 15 Cilt. B.y.: Dâru'l-Fikr, 1407/1986.

Kalkaşendî, Ebü’l-'Abbâs Ahmed b. Alî. Subbu'l-a 'şâa fî̀ smâa ati’l-inşâ. Beyrut: Dâru’l-Kütübi'l-İlmiyye, tsz.

Kallek, Cengiz "İbn Hacer el-Heytemî". Türkiye Diyanet Vakfi İslâm Ansiklopedisi. 19/531-534. Ankara: TDV Yayınları, 1999.

Kehhâle, Ömer Rızâ. Mu'cemü'l-mü'ellifinn: Terâcimü musannifi'l-kütübi'l'Arabiyye. 15 Cilt. Beyrut: Dâru İhyâi't-Türâsi'l-'Arabî, tsz.

Kılıç, Muhammed Tayyib. "Hint Alt Kıtası Hanefî Fıkıh Birikimine Bir Örnek: Fakih Olarak İmâm Leknevî”. 16/1 (2014), 89-140.

Komisyon. Indian writungs in Arabıc. University Of Calıcut School Of Distance Education, tsz.

Kürdî, Şemsüddîn Muhammed b. Süleymân el-Medenî. el-Fevâ'idüllmedeniyye fî-men yüftâ bi-kavlibî min e'immeti's-Şafi' iyye (müte' ahhiri'ssâdeti'ş-Şafi îyye). Dimaşk: Dâru Nûru'd-Sabâh, 1432/2011.

Meğrâvî, Ebû Sehl Muhammed b. Abdirrahman. Mevsû́atu mevâkifi's-selef fi'l-'akîde ve'l-menhec ve't-terbiyye. 10 Cilt. Misir: el-Mektebetü'lİslâmiyye, tsz.

Melîbârî, 'Abdunnesîr Ahmed. Terâcimu 'ulemâi's-Şâfî̀ye fi'd-diyâri'lHindiyye. B.y.: Dâru'l-Kalem li'd-Dirâsat ve'n-Neşri, tsz.

Melîbârî, Ahmed b. Muhammed. Fetbu'l-mu'în bi-şerbi Kurreti'l-'ayn. Beyrut: Dâru İbn Hazm, 1424/2004. 
Melîbârî, Ahmed b. Muhammed. el-Ecvibetü'l-'acîbe ani'l-es'ileti'l-garîbe. Hindistan: Dâru't-Tabâ'ati ve'n-Neşr, tsz.

Melîbârî, Ahmed b. Muhammed. el-isti'dâdu li'l-mevt ve su'âlü'l-kabr. thk. Sa'îd Kerîm ed-Dir'amî. İskenderiye: Dâru İbn Haldûn, tsz.

Melîbârî, Ahmed b. Muhammed. el-Menhecüll-vâdih bi șerbi İbkâmu abkâmi'n-nikeâh, Riyad: Câmi‘atu Melik Suud, No: 216-5/ ק.P .

Melîbârî, Ahmed b. Muhammed. İrşâdül- 'ibâd ilâ sebîli’r-reşâd. B.y.: Dâru'lMa'rife, tsz.

Melîbârî, Muhyisünne Abdulkādîr b. Muhammed. Tabkîku'l-matleb bi ta'rîfi mustalabi'l-mę̧heb mę̧hebi'l-imâmi'ş-Şâfî̀. Beyrut: Dâru'lKütübi'l-İlmiyye, tsz.

Melîbârî, Zeynüddîn b. Ahmed. Tubfetui'l-mücâbidîn fì ba'ž abbâri'lBurtugälizyin. Thk. Muhammed Saîd et-Tarîhî. Beyrut: Müessesetü'l-Vef, 1405/1985.

Nemir, 'Abdulmun'im. Târîhu'l-İslâm fi'l-Hind, Beyrut: el-Müessesetü'lCâmi'e li’d-Dirâsât, 1401/1981.

Nevevî, Ebû Zekeriyyâ Yahyâ b. Şeref b. Mürî. Minhâcü't-tâlibin ve 'umdetï'l-muftin fi'l-fikhi. B.y.: Dâru'l-Fikr, 1425/2005.

Özcan, Azmi. "Malabar". Türkiye Diyanet Vakfi İslâm Ansiklopedisi. 27/465-466. Ankara: TDV Yayınlar1, 2003.

Özel, Ahmet. "Melîbârî". Türkiye Diyanet Vakefi İslâm Ansiklopedisi. 29/4849. Ankara: TDV Yayınları, 2004.

Remlî, Şihâbüddîn Ahmed b. Ahmed b. Hamza el-Enșârî. Fetâva'r-Remlî. 4 Cilt. B.y.: el-Mektebetü’l-İslâmiyye, tsz.

Şensoy, Sedat. "Şerh". Türkiye Diyanet Vakfi İslâm Ansiklopedisi. 38/555558. Ankara: TDV Yayınlar1, 2010.

Şensoy, Sedat. "Ta'lîkât". Türkiye Diyanet Vakfi İslâm Ansiklopedisi. 39/508-510. Ankara: TDV Yayınları, 2010.

Şirvânî, Abdulhamîd. Havâşi’ş-Şirvânî (Tuhfetü'-Imubtac ile birlikte). 10 Cilt. Misır: el-Mektebetü’t-Ticâriyye, 1357/1987.

Topuzoğlu, Tevfik Rüsstü. "Hâşiye". Türkiye Diyanet Vakefi İslâm Ansiklopedisi. 16/419-422. Ankara: TDV Yayınlar1, 1997. 
Yaşar, Mehmet Aziz. Memlukkler döneminde fikıı siyaset ilişkisi. Ankara İlâhiyât Yayınları, 2020.

Zehebî, Muhammed b. Ahmed b. Osmân el-Fârikī. Târîhu'l-İslâm ve vefeyâtü'l-meşâhîr ve'l-a 'lâm. Thk. Beşşâr 'Avvâd Ma'rûf. 15 Cilt. b.y.: Dâru'l-Garbi'l-İslâmî, 1424/2003.

Zeydân, Corcî. Târîhu âdâbi'l-lugati'l-'arabî. Kahire: Müessesetu Hindâvî li't-Ta'lîmi ve's-Sikâfe, 2013.

Ziriklî, Muhammed Hayrüddîn b. Mahmûd. el-A lâm. Bask1 15. 8 Cilt. B.y.: Dâru'l'İlim li'l-Melâyin, 1423/2002.

Zuhaylî, Vehbe b. Mustafa. el-Fıkhü'l-İslâmî ve edilletühu. Suriye: Dâru'lFikr, tsz.

\section{Web Tabanlı Kaynaklar}

http://alhindiya.com/2019/12/13/ , erişim tarihi: 24.6.2020.

https://www.nidaulhind.com/2016/02/blog-post 66.html, erissim tarihi: 21.6.2020.

https://tr.wikipedia.org/wiki/Hindistan $\% 27 \mathrm{da} \% \mathrm{C} 4 \%$ B0slam, erişim tarihi: 28.5.2020.

http://www.alhabibomar.com/Lessons.aspx?SectionID=7, erişim tarihi: 23.6.2020

http://rebatalfateh1030.blogspot.com/, erişim tarihi: 4.7.2020.

https://www.nidaulhind.com/2017/04/blogpost 21.html?fbclid=IwAR3SkoHrhukI0HlO9jWP3hPLJCK17OYFNI AnHIYuBJuC5uuQ96bGRu2vqC0 4.7.2020.

http://www.awqaf-damas.com/?page=search; erişim tarihi: 22.6.2020. 